\title{
Current scenario of CNG vehicular pollution and their possible abatement technologies: an overview
}

\author{
Suverna Trivedi ${ }^{1,2} \cdot$ Ram Prasad $^{1} \cdot$ Ashuthosh Mishra $^{1,3} \cdot$ Abul Kalam $^{4,5} \cdot$ Pankaj Yadav $^{6}$ \\ Received: 3 February 2020 / Accepted: 3 August 2020 / Published online: 15 August 2020 \\ (C) Springer-Verlag GmbH Germany, part of Springer Nature 2020
}

\begin{abstract}
Compressed natural gas is an alternative green fuel for automobile industry. Recently, the Indian government is targeting to replace all the conventional fuel vehicles by compressed natural gas (CNG) automobiles due to its several merits. Still, the presence of a significant amount of $\mathrm{CO}, \mathrm{CH}_{4}$, and $\mathrm{NO}_{x}$ gases in the $\mathrm{CNG}$ vehicle exhaust are quiet a matter of concern. Thus, to control the emissions from $\mathrm{CNG}$ engines, the major advances are under development of and oxidation is one of them in catalytic converter. In literature, the catalysts such as noble and non-noble metals have been reported for separate oxidation of $\mathrm{CO}$ and $\mathrm{CH}_{4}$. Experimentally, it was found that non-noble metal catalysts are preferred due to its low cost, good thermal stability, and molding tractability. In literature, several articles have been published for $\mathrm{CO}$ and $\mathrm{CH}_{4}$ oxidation but no review paper is still available. Thus, the present review provides a comprehensive overview of separate as well as simultaneous $\mathrm{CO}_{\text {and }} \mathrm{CH}_{4}$ oxidation reactions for $\mathrm{CNG}$ vehicular emission control.
\end{abstract}

Keywords Green fuel $\cdot \mathrm{CNG}$ vehicle $\cdot \mathrm{CO}-\mathrm{CH}_{4}$ emission $\cdot$ Catalytic control $\cdot$ Spinel catalyst

\section{Introduction}

Internal combustion (IC) engines are used in various fields like transportation, agriculture, power generation, industries, defense, etc. However, the incomplete combustion inside the IC engines emits primary pollutants like carbon monoxide (CO), unburned hydrocarbon $(\mathrm{HC})$, nitrogen oxides $\left(\mathrm{NO}_{x}\right)$,

Responsible Editor: Philippe Garrigues

Suverna Trivedi

suverna.pdpu@gmail.com

1 Department of Chemical Engineering, Indian Institute of Technology, Banaras Hindu University, Varanasi, India

2 Department of Chemical Engineering, National Institute of Technology, Rourkela, Odisha, India

3 Department of Environment Engineering, CSIR, National Environment and Engineering Research Institute, Noida, India

4 Department of Chemistry, College of Science, King Khalid University, Guraiger, Saudi Arabia

5 Research Center for Advanced Materials Science (RCAMS), King Khalid University, Guraiger, Saudi Arabia

6 Department of Solar Energy, Pandit Deendayal Petroleum University, Gandhinagar, Gujarat 382 007, India and soot/particulate matters into the atmosphere (Veldsink et al. 1995). These primary pollutants are precursors for the formation of secondary pollutants such as peroxyacrylonitrile (PAN), polycylic aeromatic hydrocarbon, acid rain, smog, tropospheric ozone, etc. (Prasad and Singh 2012). Both these pollutants are playing a major role in global warming and climate change. Intially, air pollution was considered a local issue (impacting air quality, public health, ecosystem, storm, cloud burst, drought, etc.), but later on, it is recognized as an intricate problem of regional (acid deposition, atmospheric haze, impact on vegetation, etc.) as well as global influences (greenhouse effect, climate change, and stratospheric ozone depletion) (National Research Council 2010; Task Force on Hemispheric Trasnport of Air Pollution (HTAP) 2007).

It is belived that combustion of conventional fossil fuels such as gasoline and diesel may even get an increase by threefold by 2050 due to the ever increasing number of vehicles on the road (Andrews and Shabani 2012). The vehicles running on fossil fuels have made living easy and convenient; on the other hand, they have also made human life more complex and in danger because of their toxic emissions; so, vehicle is a "necessary evil." In view of protecting the health and ecology, motivation toward the use of alternative fuels with low emissions for vehicles has been growing from the last few years. Compressed natural gas $(\mathrm{CNG})$ has emerged as an attractive 
alternative fuel for IC engines (Bhandari et al. 2005; Christensen and Johansson 1998). In the last few years, CNG vehicles on the road has been increasing exponentially around the globe as mentioned in Fig. 1 due to numerous advantages over other fossil fuels. There were more than 24 million CNG vehicles worldwide by August 2017 (Perry 2017).

From Fig. 2, it can be seen that a number of $\mathrm{CNG}$ vehicles is continuously increasing worldwide and reaches to 26.13 million in 2018. Thus, it is expeted that more than 30 million of CNG vehicles will run on the road till 2021.

\section{CNG as an alternative eco-friendly fuel}

The CNG is a natural gas maintained under pressure of 200250 bars which remains clear, odorless and non-corrosive. It consists of high content of $\mathrm{CH}_{4}$ gas which produces engine power when mixed with air and combust in IC engines. The constituent gas composition of CNG also varied depending upon the source of origin, as mentioned in Table 1.

The CNG can be produced in industry via three typical methods, thermogenic (thermal treatment), biogenic (biological treatment), and mixed (includes thermal as well as biological treatment). CNG produced by thermogenic method contains relatively higher concentration of $\mathrm{CH}_{4}(>60 \%)$ as compared with biogenic methane (60\%) and mixed concentration (50-60\%) (Faramawy et al. 2016). Depending upon the production of $\mathrm{CNG}$, it consists of some other hydrocarbon and non-hydrocarbons apart from $\mathrm{CH}_{4}$ in its composition. These constituents are higher hydrocarbons $\left(\mathrm{C}_{3} \mathrm{H}_{8}, \mathrm{C}_{4} \mathrm{H}_{10}\right.$, etc.), $\mathrm{He}$, diluents $\left(\mathrm{CO}_{2}\right.$ and $\mathrm{N}_{2}$ ), and contaminants (sulfur, $\mathrm{Hg}$, As, naturally occurring radioactive materials, solid matter, etc. (Faramawy et al. 2016). The CNG has several advantages in comparison with conventional-fuelled vehicles. The comparison of different physical and thermodynamic properties of CNG with fossil fuels is mentioned in Table 2.

From Table 1, it can be observed that CNG consisting of > $90 \% \mathrm{CH}_{4}$ has the lowest $\mathrm{C} / \mathrm{H}$ ratio among the other $\mathrm{HCs}$ present in conventional fuel with a relatively less than 20 $30 \% \mathrm{CO}_{2}$ and particulate matter emission that indicates it is an eco-friendly fuel (Nwaoha and Iyoke 2013). It has higher octane rating $\sim 130$ and auto-ignition temperature of $540{ }^{\circ} \mathrm{C}$ as against diesel's $260^{\circ} \mathrm{C}$ which provides $\mathrm{CNG}$ additional safety, as shown in Table 2 (Haq et al. 2003; Wright 2015). Moreover, CNG fuel has some other benefits in comparison with gasoline and diesel-fuelled vehicles, as mentioned below:

- $\mathrm{CNG}$ is abundant in nature. Furthermore, being in a gaseous form, no distillation is required, thus the production cost of $\mathrm{CNG}$ is $\sim 50 \%$ lower than petrol or diesel.

- It is a safe fuel, being lighter than air; it disperses into the atmosphere in case of any leakage. If its concentration in the air is less than $5 \%$ or more than $15 \%$, the gas will not burn even in the presence of a spark (Haq et al. 2003).

- The CNG is adulteration free. When it enters in the engine in gaseous form (and not as a spray or mist like other fuels), it does not contaminate or dilute lubricating oil thus increasing the life of lubricating oils (Bhandarkar and Nijagunappa 2016).

- The CNG reduces chances of wear and tear and prolongs the life of an engine (Hossain 2014).
Fig. 1 Application of CNGfuelled engines in various fields

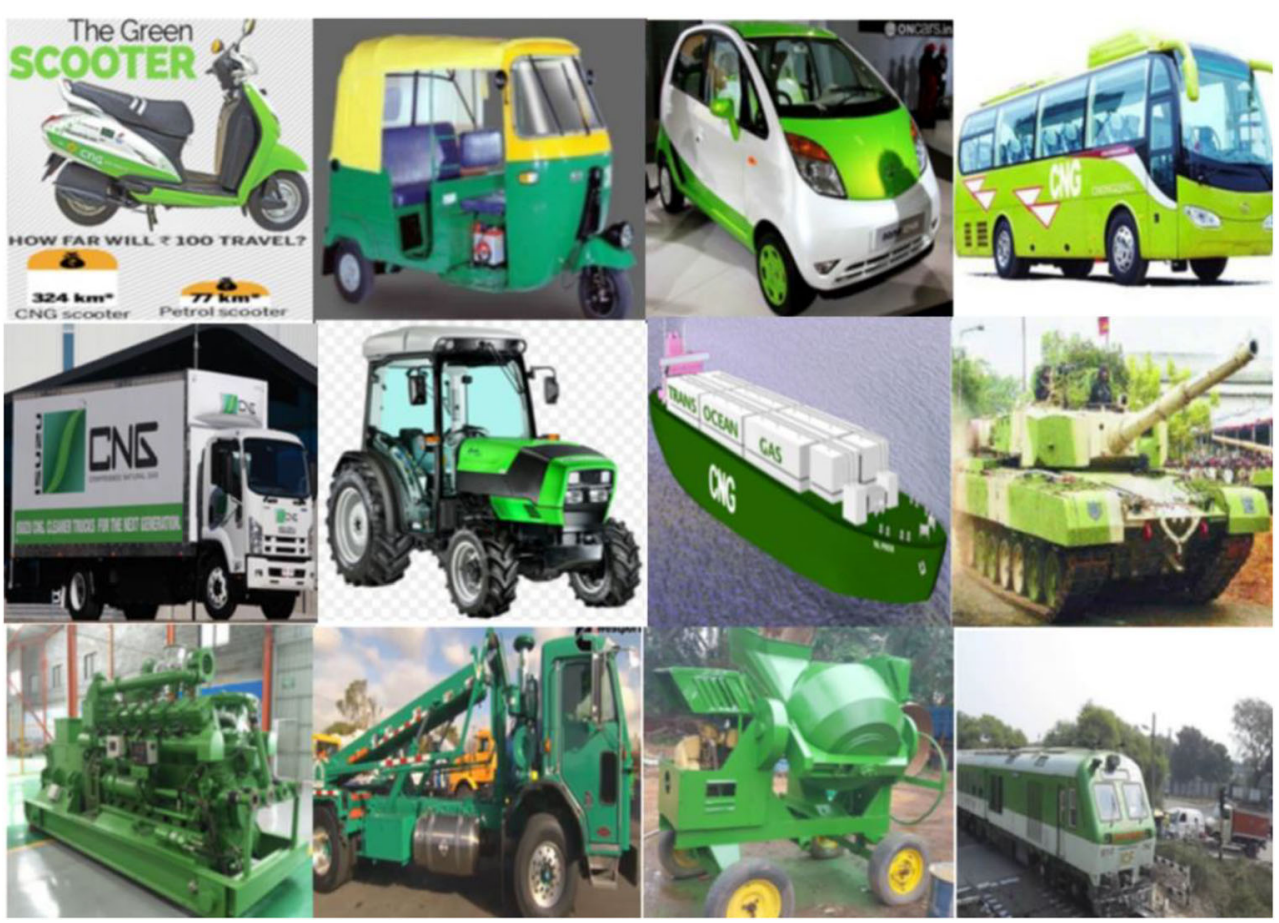


Fig. 2 Growth of total $\mathrm{CNG}$ vehicles in the world from 2000 to 2020 (Perry 2017)

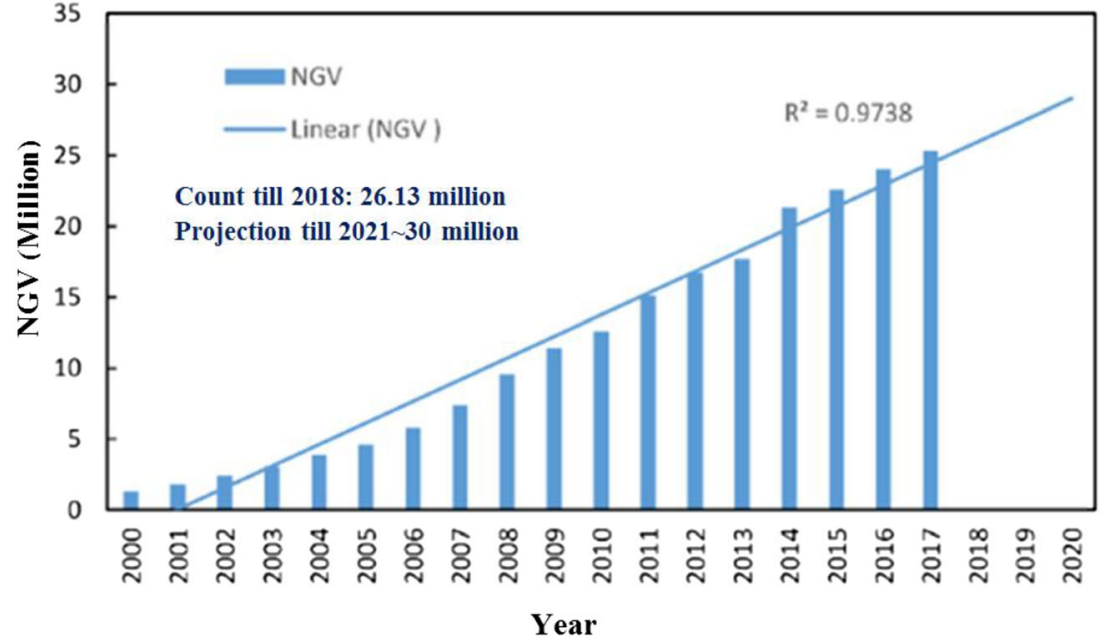

- The CNG avoids fouling of spark plugs, thereby enhancing plug life and have low operational and maintenance costs (Khan et al. 2015).

- It can be used efficiently in spark ignition (SI) as well as compression ignition (CI) engines (Cho and He 2007; Christensen and Johansson 1998).

- It has superior starting even under severe cold or hot weather conditions, reliable idling, and smooth acceleration (Nwaoha and Iyoke 2013).

- In comparison with diesel/petrol, $\mathrm{CNG}$ has wide applications in various fields such as transportationscooter, car, bus, truck, train, and ship; industries; agriculture-tractor (Kamel et al. 2002), pumping set, and thresher; power generation (Spath and Mann 2000); mining and construction equipment; security-mechanized guns and battle tanks; etc. (Fig. 1).

\section{CNG-allied engines}

The substitution of conventional fuel-based (gasoline/diesel) vehicles for road transport can be attained by introducing new vehicles equipped with $\mathrm{CNG}$ engines in the market. The following options are available for the conversion of conventional engines by $\mathrm{CNG}$ for road transport:

- Dedicated fuel: A dedicated CNG vehicle is one that runs only on CNG fuel. It can be either a new CNG vehicle or modified gasoline engines to $\mathrm{CNG}$. The dedicated $\mathrm{CNG}$ vehicles have higher engine efficiencies than either petrol or diesel, which means higher compression ratios due to high octane number of CNG (Kowalewicz and Wojtyniak 2005).

- Bi-fuel: Bi-fuel engines are also called "switchable" systems because it can be switched between gasoline or CNG. Most conversions are done for light-duty (cars and
Table 1 Composition of CNG fuel based on its source of origin (Semin 2008)

\begin{tabular}{lllll}
\hline \multirow{2}{*}{ Components } & \multicolumn{2}{l}{ CNG fuel composition in volume fraction $(\%)$} & \\
\cline { 2 - 5 } & Speight (2013) & Heywood (1988) & Kowalewicz (1984) & Stone (1999) \\
\hline Methane $\left(\mathrm{CH}_{4}\right)$ & 84.6 & 94.00 & 92.07 & 94.39 \\
Ethane $\left(\mathrm{C}_{2} \mathrm{H}_{6}\right)$ & 6.4 & 3.30 & 4.66 & 3.29 \\
Propane $\left(\mathrm{C}_{3} \mathrm{H}_{8}\right)$ & 5.3 & 1.00 & 1.13 & 0.57 \\
Iso-Butane $\left(\mathrm{i}-\mathrm{C}_{4} \mathrm{H}_{10}\right)$ & 1.2 & 0.15 & 0.21 & 0.11 \\
$n$-Butane $\left(n-\mathrm{C}_{4} \mathrm{H}_{10}\right)$ & 1.4 & 0.20 & 0.29 & 0.15 \\
Iso-Pentane $\left(i-\mathrm{C}_{5} \mathrm{H}_{12}\right)$ & 0.4 & 0.02 & 0.10 & 0.05 \\
$n$-Pentane $\left(n-\mathrm{C}_{5} \mathrm{H}_{12}\right)$ & 0.2 & 0.02 & 0.08 & 0.06 \\
Nitrogen $\left(\mathrm{N}_{2}\right)$ & $\leq 10$ & 1.00 & 1.02 & 0.96 \\
Carbon dioxide $\left(\mathrm{CO}_{2}\right)$ & $\leq 5$ & 0.30 & 0.26 & 0.28 \\
Hexane $\left(\mathrm{C}_{6}{ }^{+}\left(\mathrm{C}_{6} \mathrm{H}_{14}\right)\right)$ & 0.0 & 0.01 & 0.17 & 0.13 \\
Oxygen $\left(\mathrm{O}_{2}\right)$ & 0.0 & - & 0.01 & $<0.01$ \\
Carbonmonoxide $(\mathrm{CO})$ & 0.0 & - & $<0.01$ & $<0.01$ \\
\hline
\end{tabular}


Table 2 Comparison of CNG with conventional fuel on the basis of physical and thermodynamic properties (Wright 2015)

\begin{tabular}{llll}
\hline Properties & \multicolumn{2}{l}{ Fuel } & \\
\cline { 2 - 4 } & Gasoline & Diesel & $\mathrm{CNG}$ \\
\hline General formula & $\mathrm{C}_{8} \mathrm{H}_{18}$ & $\mathrm{C}_{12} \mathrm{H}_{23}$ & $\mathrm{CH}_{4}$ \\
$\mathrm{C}$ content & $4-12$ & $12-20$ & 1.0 \\
Average molecular weight & 50 & 178.6 & 16 \\
Stoichiometric air/fuel ratio by mass & 14.70 & 14.5 & 17.20 \\
Octane Number (RON/MON) & 92.98 & - & $120-130$ \\
Cetane Number & - & $45-55$ & - \\
Higher heating value (MJ/kg) & 45.70 & 47 & 50.30 \\
Lower heating value $(\mathrm{MJ} / \mathrm{kg})$ & 42.90 & 43 & 50.10 \\
Flammability limits $($ vol. $\%$ in air) & $1.4-7.6$ & $0.6-5.5$ & $4.3-15$ \\
Adiabatic flame temperature $(\mathrm{K})$ & 2138 & 2477 & 2266 \\
Auto ignition temperature $\left({ }^{\circ} \mathrm{C}\right)$ & 300 & 230 & 540.0 \\
\hline
\end{tabular}

vans) bi-fuel engines because they provide the best experience of both the fuels. These types of vehicles are free from the danger of running out of fuel in the case of limited CNG refueling stations (Kowalewicz and Wojtyniak 2005).

- Dual fuel: A dual-fuel engine utilizes a mixture of CNG and diesel, with diesel as a "pilot" ignition source. The diesel is injected directly into the combustion chamber, while gas is introduced into the air intake by carburetion or by gas injection. The engines run mostly on diesel at low loads, i.e., idling engine condition, but using a mixture of two fuels $(\sim 80-90 \%)$ at higher load condition (Kowalewicz and Wojtyniak 2005).

\section{Challenges of CNG vehicles}

In spite of several advantages, $\mathrm{CNG}$ vehicles have the following challenges also and some of them are listed below:

- Fuel storage: $\mathrm{CNG}$ tanks requires a much larger volume to store the same mass of natural gas as compared with other fuels and also needs a very high pressure of $\sim 200$ bars or 2900 psi (Pascoli et al. 2001).

- Lack of fuelling stations: CNG filling stations have limited availability. If car users might drive to locations that are not equipped with $\mathrm{CNG}$ stations, they move toward more convenient fuel that is easily accessible everywhere (Sierzchula et al. 2012).

- Exponential growth of the CNG-fuelled vehicles would necessitate a new gas pipelines, new refueling stations, and other infrastructure.

- Emissions of undesired gases like unburned hydrocarbon $\left(\mathrm{CH}_{4}\right), \mathrm{CO}$, and formaldehyde $(\mathrm{HCHO})$ in the exhaust that is directly affecting the environment and ambient air quality (Corrêa and Arbilla 2005; Trivedi and Prasad 2016).

\section{CNG vehicular emissions}

CNG vehicles emit a significant amount of $\mathrm{CH}_{4}$ as a slip and $\mathrm{CO}$ and $\mathrm{HCHO}$ gases due to partial oxidation. These gases are harmful to human beings, the environment, and the ecosystem. The possible mechanism for the formation of $\mathrm{CO}$ and HCHO is explained by Eq. (1). The oxidation reactions involving intermediate species like $\mathrm{HCHO}$ finally lead to formation of $\mathrm{CO}$.

$\mathrm{CH}_{4} \rightarrow \mathrm{CH}_{3}{ }^{\circ} \rightarrow \mathrm{CH}_{3}{ }^{\mathrm{o}}+\mathrm{O}_{2} \rightarrow \mathrm{HCHO} \rightarrow \mathrm{CO}$

In real situation, the complete combustion of $\mathrm{CH}_{4}$ is not possible. Thus, a significant amount of unburned $\mathrm{CH}_{4}$ is present in the exhaust gases of the engines. Under ideal conditions, the combustion of $\mathrm{CH}_{4}$ should produce $\mathrm{CO}_{2}, \mathrm{H}_{2} \mathrm{O}$, and energy, as represented by Eq. (2).

$$
\begin{aligned}
& \mathrm{CH}_{4}(\mathrm{~g})+2 \mathrm{O}_{2}(\mathrm{~g}) \rightarrow \mathrm{CO}_{2}(\mathrm{~g})+2 \mathrm{H}_{2} \mathrm{O}(\mathrm{l}) \quad \Delta \mathrm{H}_{r}^{o} \\
& =-890 \mathrm{~kJ} \mathrm{~mol}^{-1}
\end{aligned}
$$

A typical automobile exhaust contains approximately $0.5-$ 6.4\% CO, 300-1000 ppm hydrocarbon (HCs), and 50$3000 \mathrm{ppm} \mathrm{NO}{ }_{x}$. The variation in the concentration of vehicles' exhaust gases depends upon the running condition of the vehicles (Parida 1992). Generally, CNG engines run at lean conditions to maintain low combustion temperature and have low $\mathrm{CO}$ emissions. The emissions from the $\mathrm{CNG}$ automobiles depend upon the operating conditions of engine such as rich or lean, acceleration, deceleration, cruising, road conditions, traffic conditions, etc. The lean and rich conditions are decided by the value of lambda $(\lambda)$, which is a ratio of actual air/fuel to stoichiometric air/fuel. When $\lambda=1$, air/fuel mixture is stoichiometric; for $\lambda<1$, the mixture is rich in fuel; and while $\lambda>1$, the mixture is lean in fuel (Cho and He 2008; Ly 2002). The lean-burn engines can work on high compression ratios and thus offer better performance in comparison with conventional stoichiometric engines. So, lean-burn engines are preferred at present due to their inherently lower exhaust $\mathrm{CO}, \mathrm{HC}$, and $\mathrm{NO}_{x}$ emissions compared with stoichiometric engines. Lean-burn engines are also able to provide power and torque levels similar to those of conventional engines. They are more fuel efficient than conventional engines. Lean-burn engines' concepts are used in both light-duty as well as heavy-duty vehicles. The emissions from IC engines under rich and lean conditions are represented in Fig. 3.

The emission characteristics are in general for all types of fuels used in the SI engines. It is clearly seen from the figure 
Fig. 3 Emission from IC engines (Ly 2002)
Stoichiometric mix 3 -way catalyst

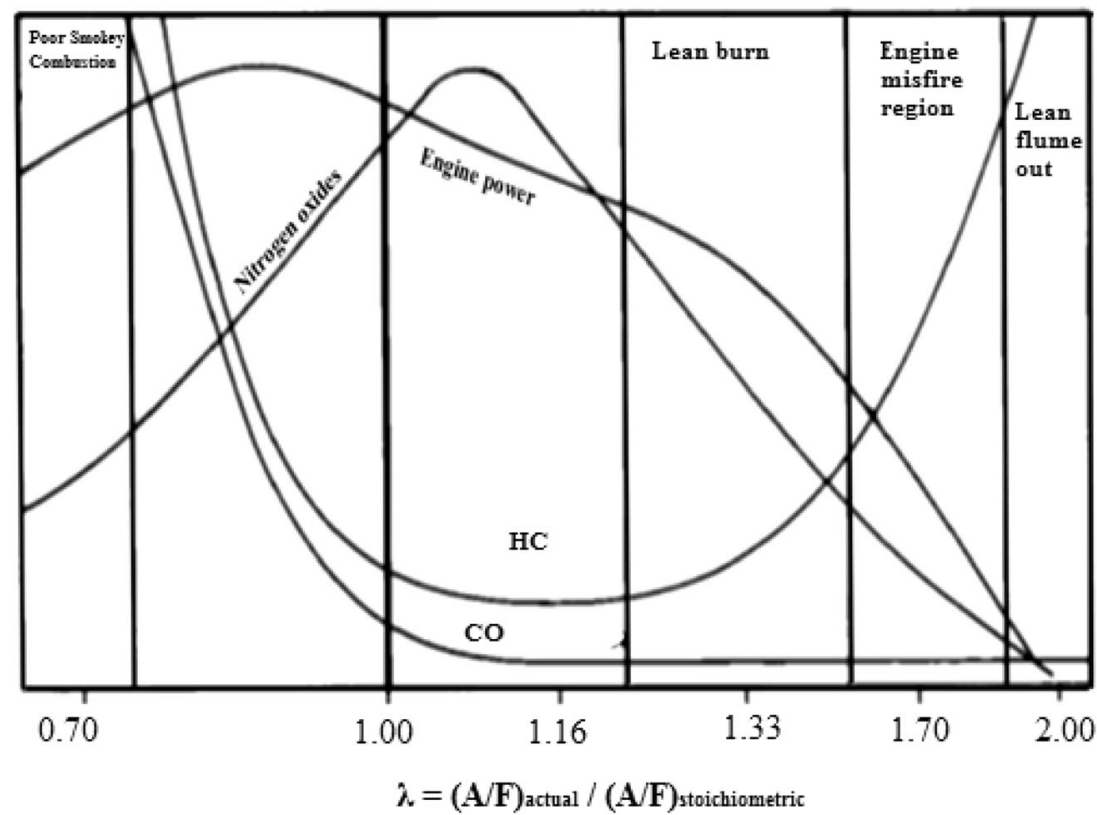

that high hydrocarbon (HC) emissions occur from the vehicles at fuel-rich condition $(\lambda<1)$ and decreases to a minimum at lean of stoichiometry, but it increases again in the lean-burn region $(\lambda>1)$ where the oxidation temperature is lowered by the dilution with excess oxygen and nitrogen. The $\mathrm{CO}$ emission from the vehicles is the least in lean-burn conditions. However, $\mathrm{NO}_{x}$ emission is high on the lean side of stoichiometry. The presence of excess air causes thorough combustion at a lower temperature, resulting the least $\mathrm{CO}$ as well as low $\mathrm{NO}_{x}$ formation. As the fuelling moves further into the leanburn region, $\mathrm{NO}_{x}$ emissions fall sharply and $\mathrm{CO}$ emissions are at a minimum. However, $\mathrm{HC}$ emissions increase and engine power falls. Ultimately, the lean misfire and flame-out regions are reached, where $\mathrm{HC}$ emissions are very high and the power drops sharply.

\section{Adverse impact of $\mathrm{CH}_{4}$ and $\mathrm{CO}$ emissions}

$\mathrm{CH}_{4}$ (known as direct "greenhouse gas") has tetrahedron structure (Fig. 4), and it is a colorless as well as odorless
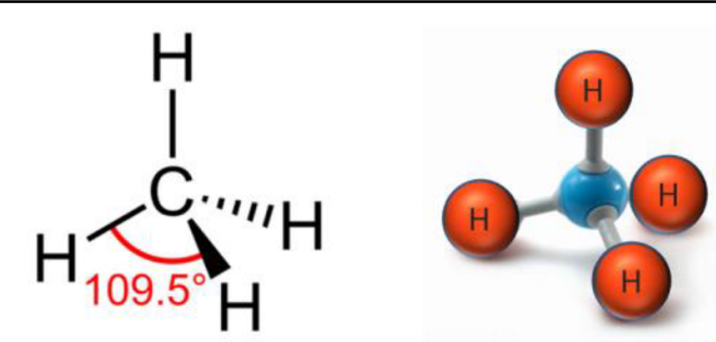

Fig. $4 \mathrm{CH}_{4}$ and its structure gas. In general, hydrogen sulfide (which smells like rotten egg) is usually mixed with $\mathrm{CNG}$ in order to detect during leakage (O'Brien et al. 2004). In a perspective of climate effect, $\mathrm{CH}_{4}$ is 23 times more potent than $\mathrm{CO}_{2}$ in trapping heat in Earth's atmosphere (Trivedi and Prasad 2016) .

$\mathrm{CO}$ is a colorless, odorless, tasteless, and non-irritating poisonous gas produced during the burning of organic fuel. It is $96.5 \%$ as heavy as air and is not appreciably soluble in water. It has also been labeled as "the unnoticed poison of the twenty-first century" and is frequently called "the silent killer," because it gives no clear warning to its victims. Inhaling even relatively small amounts of $\mathrm{CO}$ can lead to hypoxic injury, neurological damage, and even death. It does not only affect human beings but also vegetation.

\section{Effect on human health}

Epimiological and clinical studies provide evidence for a progression of some of the adverse health effects of $\mathrm{CO}$ in humans. $\mathrm{CO}$ is a deadly and treacherous gaseous pollutant. $\mathrm{CO}$ poisoning interferes with the normal functioning of hemoglobin as a transporting agent for oxygen in blood.

The oxygen-carrying capacity of the blood depends upon the affinity of hemoglobin in the red blood cells. Moreover, it is found that hemoglobin has 210 times higher affinity for $\mathrm{CO}$ as compared with oxygen. Hemoglobin reacts with $\mathrm{CO}$ and forms a stable product called carboxy-hemoglobin, as shown in Fig. 5a. The formation of carboxy-hemoglobin reduces oxygen delivery capabilities of the blood to the body's organs (like the heart and brain) and tissues. The symptoms of diseases at various concentrations of $\mathrm{CO}$ in the atmosphere are demonstrated in Fig. 5b. The high concentration of $\mathrm{CO}>$ 

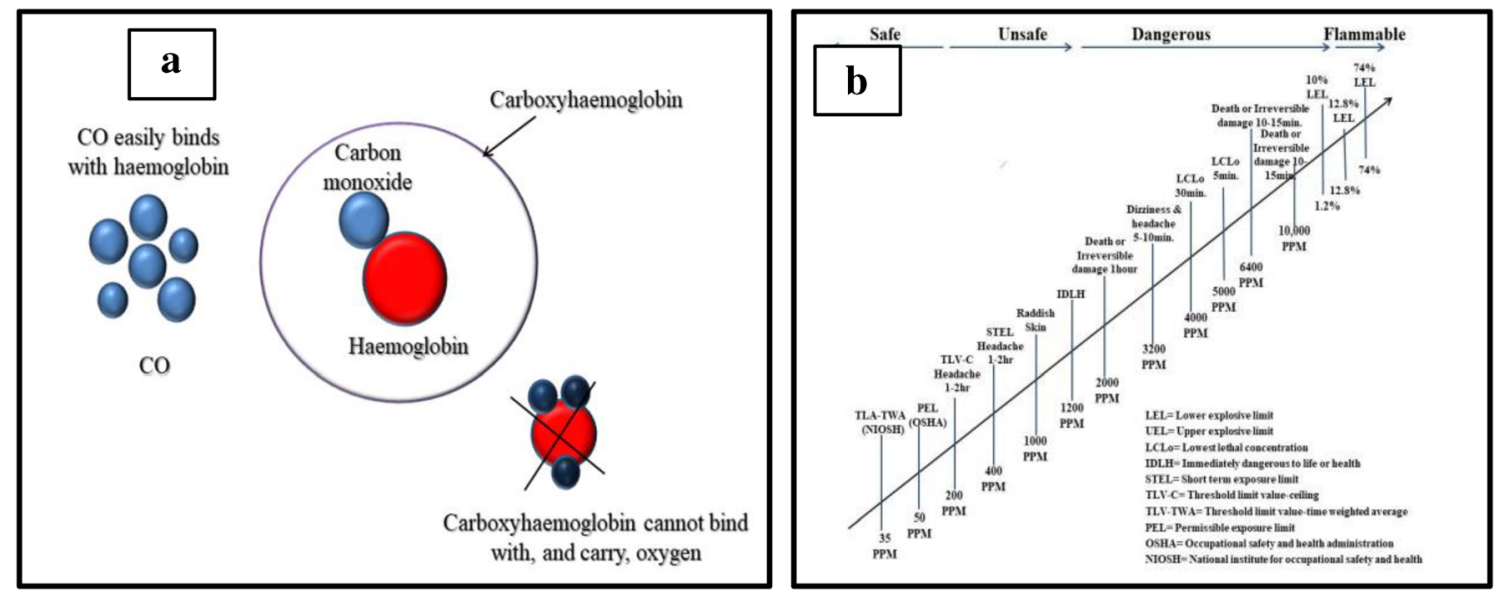

Fig. 5 a Formation of carboxy-hemoglobin. b Effect of exposure to various concentrations of CO (O’Brien et al. 2004; Prasad and Singh 2012)

$0.1 \%$ can seriously affect human aerobic metabolism ensuing respiratory failure and resulting in death (Prasad and Singh 2012). In many countries, the most common type of lethal air poisoning is known as CO poisoning (Omaye 2002). People with several types of heart disease already have a reduced capacity for pumping oxygenated blood to the heart, which can be exaggerated by inhaling $\mathrm{CO}$ in air. Vulnerable people can be affected more than healthy ones: infant, pregnant lady, and others. While, low concentration of $\mathrm{CH}_{4}$ emission does not have a significant impact on human health directly.

\section{Effects on vegetation}

It is found that $\mathrm{CO}$ can influence the plant seed germination, inducing the adventitious rooting process (Fortunato et al. 2001). CO poisoning causes the curling of plant leaves, decreasing leaf size, and premature aging of the chlorophyll, as shown in Fig. 6. It also reduces the cellular respiration system of plants (Ghaffari et al. 2008; Xuan et al. 2008). The longterm $\mathrm{CO}$ exposure decreases the length of primary roots and also the distance from the seed to the tip of the leaf. Whereas, the direct adversarial impact of $\mathrm{CH}_{4}$ was not observed on the plants, but as a greenhouse gas, it can leave footprints by burning the plant leaves.

\section{Effects on environment}

$\mathrm{CO}$ is only a weak direct greenhouse gas but has an important indirect effect on global warming. It reacts with hydroxyl $(\mathrm{OH})$ radicals in the atmosphere, reducing their abundance. The increasing $\mathrm{CO}$ in the environment increases the global warming level and ozone layer depletion (Ogur and Kariuki 2014). It is one of the main reactive trace gases. In the atmosphere, the CO's level concentration ranges from 15 to $30 \mathrm{ppm}$; it affects the earth's radiation directly as the oxidation of $\mathrm{CO}$ would result in supplying more $\mathrm{CO}_{2}$ from the greenhouse gas (Guo et al. 2016; Rudolf 1994). While, $\mathrm{CH}_{4}$ is a direct greenhouse gas which is responsible for global warming as well as climate change problems.

Global warming and climate change are interchangeable terms according to the U.S. Environmental Protection Agency (EPA 2014). Then, climate change differs from global warming according to the National Academy of sciences (USA). Global warming is related to increasing temperature while the term "climate change" measures any significant
Fig. 6 Effect of $\mathrm{CO}$ emissions on vegetation (Prasad and Singh 2012)

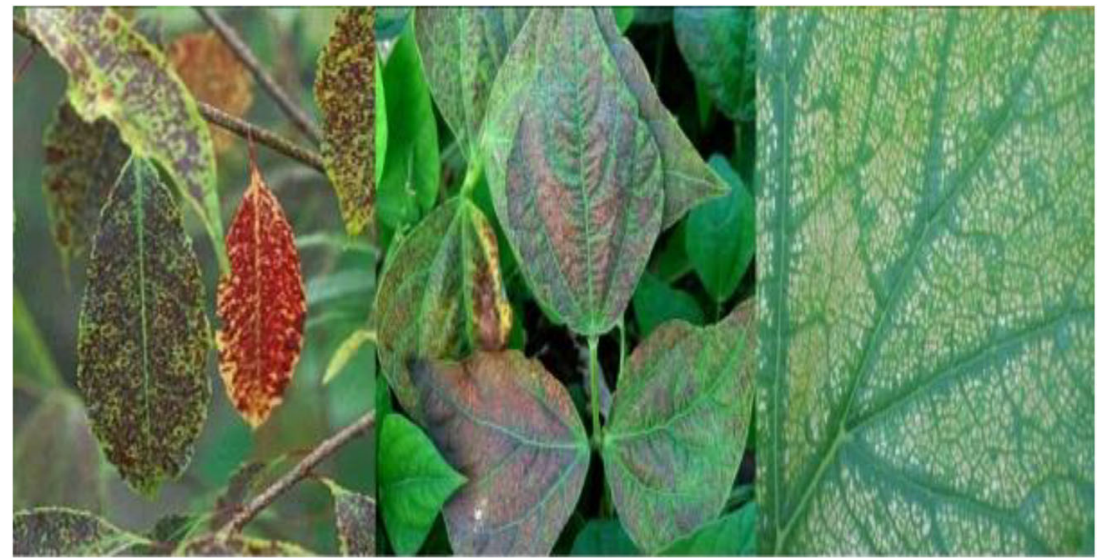


change in the climate in addition to the temperature such as precipitation or wind. Among the various countries, India is also a major contributor of greenhouse gases. Issues concerning climate change in India in the past few years include situations like heavy raining at certain places causing floods; on the other hand, drought-prone situation was observed in some areas. The problems that arise due to global warming as well as climate changes in India are discussed below:

- Melting of Gangotri glaciers was a result of an increase in atmospheric temperature (Fig. 7a, b). If the rate of glaciers' melting increases, flooding is likely in the river valleys fed by these glaciers, followed by a diminished flow, resulting in a scarcity of water for drinking and agricultural irrigation (Kaltenborn et al. 2010; Bajracharya et al. 2006).

- The agriculture in India is highly dependent upon the natural climate (o'Brien et al. 2004). The natural imbalance affects the monsoon which creates the problem in securing water for irrigating crops, resulting in below-average crop yields (Fig. 7c). The drought-prone regions in India are southern and eastern Maharashtra, Northern Karnataka, Andhra Pradesh, Odisha, Gujrat, Telangana, and Rajasthan (Fig. 7d).

- Increased precipitation is likely to come in the form of fewer rainy days but more days of extreme rainfall events, with increasing amounts of rain in each event, leading to significant flooding (Brunetti et al. 2001). For example, in June 2013, a heavy rainfall was observed in Uttarakhand due to cloud burst; a similar problem was also observed in 2014 in Jammu and Kashmir, in August 2017 in Northern India, and so on (Fig. 7d).

The above-mentioned examples reflect that the natural resources have been distorted by climate change, thereby increasing the risk of several disasters. This kind of natural calamities forced people to escape from their houses and made them environmental migrant, for example, submerged Dwarka, $120 \mathrm{ft}$ underwater in the Bay of Cambay (ARAI 2011) was discovered by marine scientists in early 2002 (Tripati et al. 2002).The city is 5 miles long and 2 miles wide; carbon dating estimates the site to be a whopping 9500 years old, as shown in Fig. 7f.

The last 5 years (2015-2019) were the warmest on the record of India, and frequency of natural distaster is increasing, for example, Cyclone Amphan (2020). The world is tackling with climate-risk mitigation challenges; the biggest example is Covid-19, a major health crisis. The climate changes are playing a crucial role in the current pandemic because rising temperature and the high frequency of extreme weather is associated with various infectious diseases. It is a serious concern, and the government is doing efforts to prevents us from this pandemic and natural disaster (Nambi Appadurai 2020).

\section{Legislations of $\mathrm{CO}$ and $\mathrm{CH}_{4}$ emissions}

The legislation has been strictly enacted increasingly into effect to set a specific limit to pollutant emissions from vehicles. Nowadays, HC emissions' limit from both stationary and nonstationary sources are becoming more stringent (Heynderickx et al. 2010). Recently, emission standards have been executed for the CNG vehicles' emission especially for heavy duty with a target to lessen it. Initially, European countries has set a specific limit of gaseous emissions for vehicular emissions to control air pollution. India is following the European norms for both light- and heavy-duty vehicles.

In 1970, the Environmental Protection Agency setup to control automobile pollution, and it is quiet in development for CNG vehicles. Further, a national auto fuel policy was broadcasted in October 2003 in which Indian emission standards are revised according to the European Union standards by introducing Euro 2-4 as Bharat Stage (BS II-IV) (Kumar et al. 2015). The Bharat stage emission standards according to the European Union for light-duty vehicles are mentioned in Table 3.

The emission standards for $\mathrm{CNG}$ vehicles run parallel to the diesel and gasoline vehicles with certain modifications. In the case of $\mathrm{CNG}$ vehicles, the mass emission standards are the same as gasoline except that the HC is replaced by nonmethane hydrocarbons (NMHCs), where $\mathrm{NHMC}=0.3 \times \mathrm{HC}$ (Kumar et al. 2015). Nowadays, Euro 6 has been implemented for particulate matter, $\mathrm{NO}_{x}$, and $\mathrm{HC}$ except $\mathrm{CH}_{4}$ for light-duty vehicles. According to the U.S. Environmental Protection Agency legislation, $\mathrm{CH}_{4}$ can be regulated at $0.1 \mathrm{~g} \mathrm{bhp}^{-1} \mathrm{~h}^{-1}$ for heavy-duty engines and $0.05 \mathrm{~g}$ mile $^{-1}$ for pickup trucks and vans (Raj 2016). Currently, the European emission standard (Euro VI) regulated the $\mathrm{CH}_{4}$ emission and NMHC separately at different test cycles, as presented in Table 4 . To meet the emission standards posed by the government, it is imperative to control these emissions of harmful gases up to a desired level. Thus, in this regard, several techniques are available in the literature.

\section{Abatement technologies of $\mathrm{CO}$ and $\mathrm{CH}_{4}$ emissions}

Since, the concentration of $\mathrm{CO}$ and $\mathrm{CH}_{4}$ in the exhaust of a CNG vehicle is always below their lower combustible limits, i.e., 4.3 and $12.0 \%$, respectively. Hence, it is not possible to flare them up by the applying flame only. Therefore, to remove them from the exhaust containing lean mixtures of $\mathrm{CO}$ and $\mathrm{CH}_{4}$, an oxidation catalyst is required. Presently, the 
Fig. 7 Impacts of global warming as well as climate change

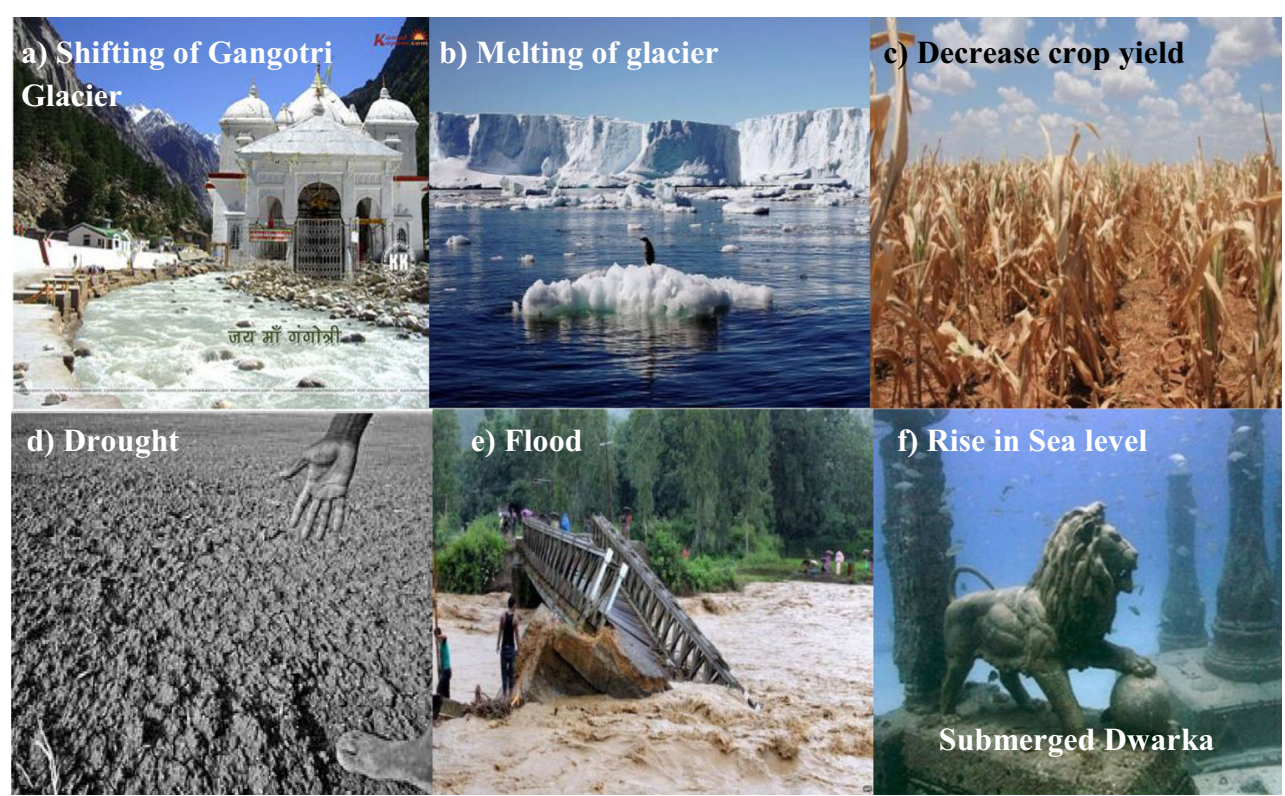

techniques used to control $\mathrm{CO}$ and $\mathrm{CH}_{4}$ emissions from $\mathrm{CNG}$ vehicles are classified into two different ways such as precombustion and post-combustion. The detailed discussion of these techniques is as follows:

\section{Pre-combustion techniques}

Pre-combustion technique is a conventional technique in which a treatment technique was applied before combustion. It includes basically engine-design modifications and technological advancement, fuel modifications using some additives, etc. These are expensive and not preferable recently. So, researchers focused toward other alternative method, i.e., know a post-combustion technique.

\section{Post-combustion technique}

This method is the most promising and economical. The concept of catalytic converter comes under this category. The

Table 3 Indian standards as per European norms for light duty vehicles (Heynderickx et al. 2010)

\begin{tabular}{lllll}
\hline Standards/norms & & Year & $\mathrm{CO}\left(\mathrm{g} \mathrm{km}^{-1}\right)$ & $\mathrm{HC}+\mathrm{NO}_{x}\left(\mathrm{~g} \mathrm{~km}^{-1}\right)$ \\
\hline 1991 norms & - & - & $14.30-27.10$ & 2 (only HC) \\
1996 norms & - & - & $8.68-12.40$ & $3.00-4.36$ \\
1998 norms & - & - & $4.34-6.20$ & $1.50-2.18$ \\
Indian stage 2000 & Euro 1 & 2000 & 2.72 & 0.97 \\
Bharat stage II & Euro 2 & 2001 & 2.20 & 0.50 \\
Bharat stage III & Euro 3 & 2005 & 2.30 & 0.35 (combined) \\
Bharat stage IV & Euro 4 & 2010 & 1.00 & 0.18 (combined) \\
Bharat stage V & Euro 5 & 2011 & - & - \\
\hline
\end{tabular}

converter is placed before the silencer without appreciable change in engine design that can convert harmful gases into non-polluted ones using a catalyst concept (Kalam et al. 2009); fo example, the lean mixture of $\mathrm{CO}$ and $\mathrm{CH}_{4}$ in the vehicle exhaust can be catalytically converted into $\mathrm{CO}_{2}$ and $\mathrm{H}_{2} \mathrm{O}$ vapor and released in the atmosphere (Eqs. 3 and 4).

$$
\begin{aligned}
& \mathrm{CO}+0.5 \mathrm{O}_{2} \rightarrow \mathrm{CO}_{2}-\Delta \mathrm{H}_{r}=-393.5 \mathrm{~kJ} \mathrm{~mol}^{-1} \\
& \mathrm{CH}_{4}+1.5 \mathrm{O}_{2} \rightarrow \mathrm{CO}_{2}+\mathrm{H}_{2} \mathrm{O} \quad-\Delta \mathrm{H}_{r}=-890 \mathrm{~kJ} \mathrm{~mol}^{-1}
\end{aligned}
$$

Eugene Houdry, a French mechanical engineer introduced the catalytic converter for the first time (Bera and Hegde 2010; Pundir 2007). In 1950, the problem of smog aroused in Los Angeles. Then, Houdry found the exact problem of air pollution which was mainly due to automobile exhaust emission. Thus, he searched out a special company named oxy-catalyst for development of catalytic converter for gasoline engine-an idea ahead of its time for which he attained a patent (US2742437). The idea of catalytic converter was really good but anti-knock agent tetra-ethyl lead would be a "poison" for converter as it forms a coating on the catalyst's surface, effectively disabling it. Later, the catalytic converter was modified by Keith at the Engelhard Corporation in 1973. Beginning in 1979 , a mandated reduction in $\mathrm{NO}_{x}$ required the design development and use of a three-way catalyst (TWC) for simultaneous abatement of $\mathrm{CO}, \mathrm{HC}$, and $\mathrm{NO}_{x}$ (Heck and Farrauto 2001; Pardiwala et al. 2011). According to the abovementioned background, the catalytic converters are of three categories: oxidation/two-, three-, and four-way converters.

The two-way/oxidation catalytic converter is applicable only for $\mathrm{CO}$ and $\mathrm{HC}$ emissions emitted from diesel-fuelled vehicles. It could convert $\mathrm{CO}$ and $\mathrm{HCs}$ into $\mathrm{CO}_{2}$ and $\mathrm{H}_{2} \mathrm{O}$ in the presence of air that is present in combustion chamber. 
Table 4 European emission standards for heavy duty natural gas vehicle (Worldwide

Emissions Standards 2016)

\begin{tabular}{llllllll}
\hline Tier & Year & Test & \multicolumn{3}{l}{ Limit $\left(\mathrm{g} \mathrm{kWh}{ }^{-1}\right)$} & & \\
\cline { 4 - 7 } & & & $\mathrm{CO}$ & $\mathrm{NMHC}$ & $\mathrm{CH}_{4}$ & $\mathrm{NO}_{x}$ & $\mathrm{PM}$ \\
\hline Euro V & 2010 & European transient cycle & 4 & 0.55 & 1.1 & 2 & 0.03 \\
Euro VI & 2014 & World harmonized transient cycle & 4 & 0.16 & 0.5 & 0.46 & 0.01 \\
\hline
\end{tabular}

Sometimes, these converters are also applicable for spark ignition engines such as gasoline in the USA market automobiles through 1981. Such catalytic converter is ineffective for controlling emission of $\mathrm{NO}_{x}$ if present in the exhaust stream. The most common reactions for two-way converters are similar to above mentioned equations (Eqs. 3 and 4). The required oxygen for oxidation reactions is available either by operating engine in lean condition or by injecting secondary air to the catalytic converter in rich-burn condition. In 1975, the twoway catalytic converters are used in rich operating condition only for $\mathrm{CO}$ and $\mathrm{HC}$ control. The $\mathrm{NO}_{x}$ was control by exhaust gas recirculation (EGR) techniques. Later, when the $\mathrm{NO}_{x}$ emission standards were made strict from 1981, the reduction catalysts were also needed in the converter. Therefore, to overcome drawback of two-way converter, the three-way converters were designed.

\section{Three-way catalytic converter}

Three-way catalytic converters (TWC) can control all three primary pollutants $\left(\mathrm{CO}, \mathrm{HCs}\right.$, and $\left.\mathrm{NO}_{x}\right)$ simultaneously in a single unit when an engine running slightly below the stoichiometric point (rich condition), as shown in the Fig. 8. The TWC contains precious metal (platinum $(\mathrm{Pt})$, palladium $(\mathrm{Pd})$, and $\mathrm{Rh}$ ) catalysts. The oxidation reaction is similar to two-way converters. The reduction reaction for $\mathrm{NO}_{x}$ control is as follows: $2 \mathrm{NO}_{x} \rightarrow x \mathrm{O}_{2}+\mathrm{N}_{2}$. As mentioned earlier, the conversion efficiency of the three pollutants present in the exhaust depends on fuel-air equivalence ratio (Fig. 9). It is very clearly seen from the figure that in excessive fuel condition when the engine is running in rich condition, the $\mathrm{NO}_{x}$ reduction is in favor over TWC. In the case of the lean-burn condition (more oxygen is present than required), only the oxidizing reactions are in favor. In today's world, people like to run the engine having an $\mathrm{A} / \mathrm{F}$ ratio of $\sim 20: 1$ or higher due to fuel economy concern. The reduction of $\mathrm{NO}_{x}$ is very difficult in oxygen-rich atmosphere. Unfortunately, the temperature of the engine increases in lean condition which makes the thermal $\mathrm{NO}_{x}$ emissions rise up.

Thus, TWC catalysts are not appropriate in lean engine condition without an additional $\mathrm{NO}_{x}$ controlling device. Therefore, to abate all three pollutants under lean-burn engine exhaust, two separate devices for oxidation of $\mathrm{CO}, \mathrm{HC}$, and soot and selective catalytic reduction of $\mathrm{NO}_{x}$ are needed. Thus, the scientists moved toward the double-layer systems.
In the double-layer system, two layers of the catalysts are in sequence and behave like a combination of oxidation and reduction catalysts. To control pollution of $\mathrm{CNG}$ vehicle, it is imperative to oxidize $\mathrm{CO}$ and $\mathrm{CH}_{4}$ using an efficient catalyst because direct combustion (flame combustion) of lean mixture of $\mathrm{CO}$ and $\mathrm{CH}_{4}$ is not possible at any temperature due to combustible limitations of their concentrations in the exhaust. Thus, the catalytic oxidation is a widely practiced method for treatment of exhaust gases from automobiles at present.

\section{Catalytic oxidation of lean $\mathrm{CO}-\mathrm{CH}_{4}$ mixture}

The catalytic oxidation reaction occurred on the bed of catalyst when air-fuel mixture passed through it on a particular temperature. Heat liberates during reaction which produces products after complete combustion, such as $\mathrm{CO}_{2}$ and $\mathrm{H}_{2} \mathrm{O}$. The total oxidation of $\mathrm{CH}_{4}$ within the range of the vehicular exhaust temperature is a very tedious task due to a strong $\mathrm{C}-\mathrm{H}$ bond. Thus, it is vital to investigate an appropriate catalyst which can oxidize $\mathrm{CH}_{4}$ along with $\mathrm{CO}$ at within the range of $150-450{ }^{\circ} \mathrm{C}$. In literature, many catalysts such as platinum group metal (PGM) catalysts (Gelin et al. 2003; Mahara et al. 2017; Zhang et al. 2014; Zorn et al. 2010), perovskite (Alifanti et al. 2007; Ciambelli et al. 2001; Forni and Rossetti 2002; Kucharczyk 2015; Liu et al. 2013; Najjar et al. 2011; Wang et al. 2012), hydrotalcite (Cheng et al. 2008; Genty et al. 2015; Jiang et al. 2010; Liu et al. 2014; MartínezLozano et al. 2007; Mokhtar et al. 2010; Saber and Zaki 2014; Takehira et al. 2004), mixed metal oxides (BiabaniRavandi and Rezaei 2012; Dongsheng et al. 2010; Heo et al. 2014; Li et al. 2009; Trivedi and Prasad 2016), and spinel (Cunningham et al. 1994; Jansson 2000; Tang et al. 2009; Tao et al. 2015; Trivedi and Prasad 2017b; Trivedi and Prasad 2018) is available for individual $\mathrm{CO}$ and $\mathrm{CH}_{4}$ oxidation. The PGM catalysts are highly active for oxidation, but their application is limited due to high cost, rare availability, sensitive to poisons, and sintering at high temperatures. Therefore, search for the less or PGM-free catalysts are of worldwide research and commercial importance. So, to fulfill the gap in literature, our motivation is to search an efficient catalyst for oxidation of $\mathrm{CO}-\mathrm{CH}_{4}$ mixture. The catalysts for separate as well as total oxidation of $\mathrm{CO}$ and $\mathrm{CH}_{4}$ are broadly 
Fig. 8 Three-way catalytic converter

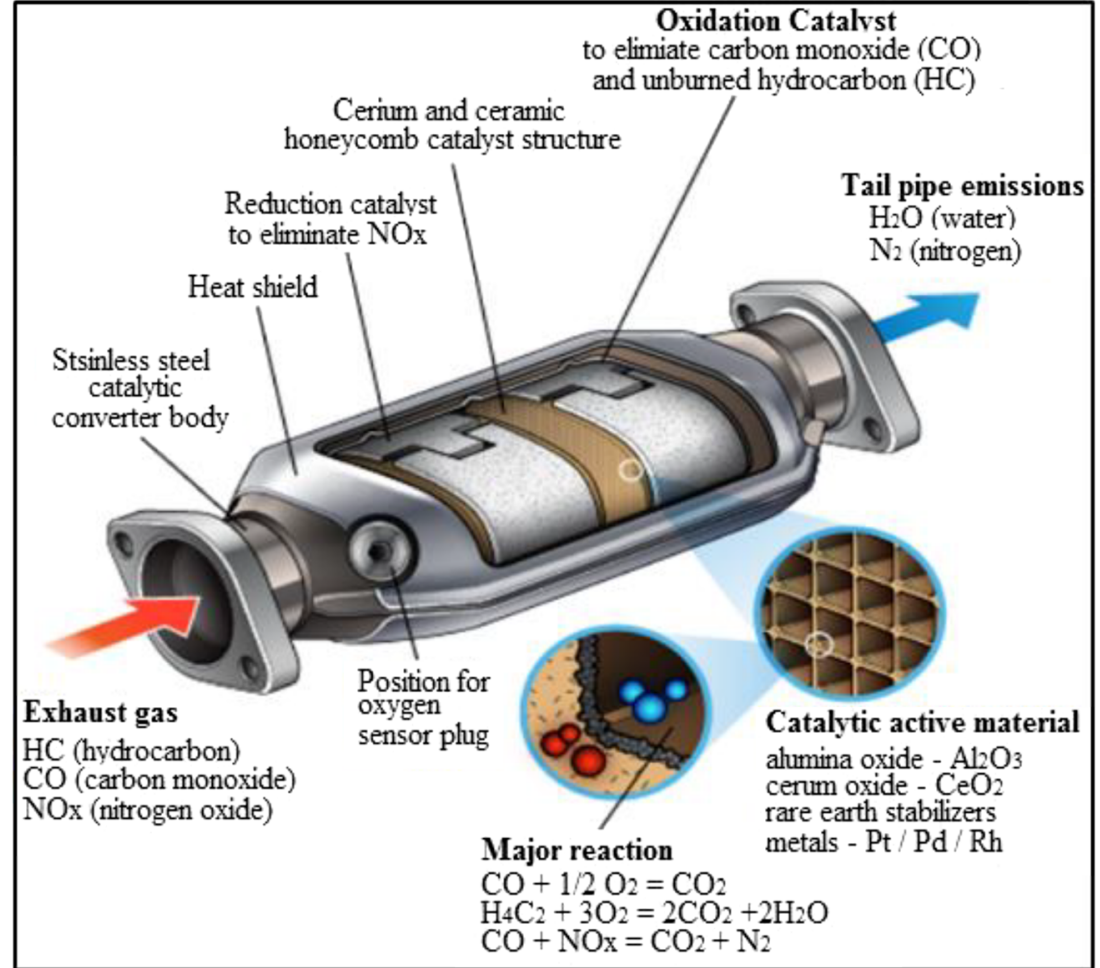

classified into two categories: precious and transition metalbased catalysts.

- Precious metal catalysts:

- Platinum group metal and

- Gold

- Transition metal catalysts:

- Perovskite,

- Hydrotalcite,

- Mixed metal oxides, and

- $\quad$ Spinel

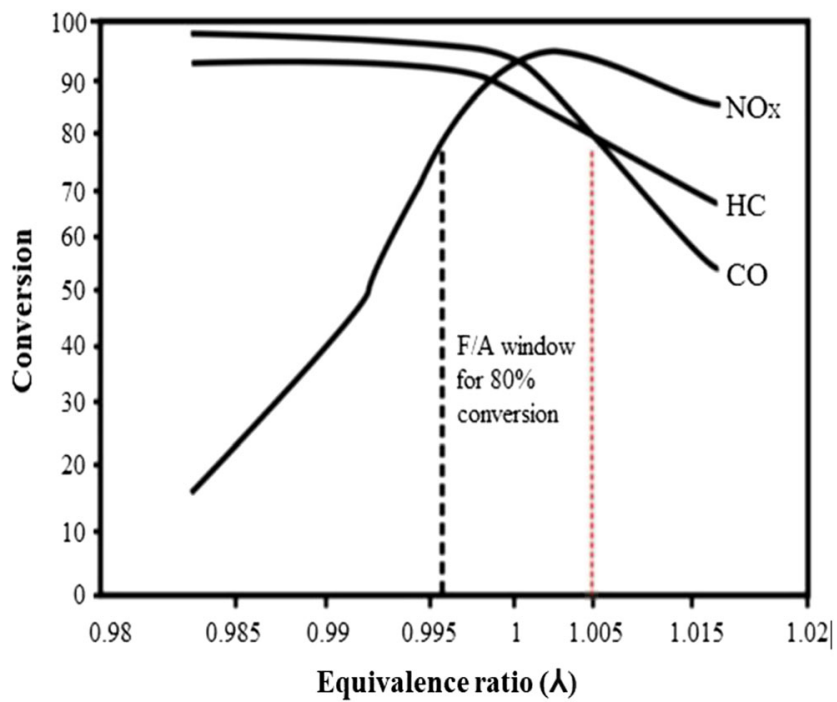

Fig. 9 Conversion efficiency of pollutants depends on equivalence ratio
The above-mentioned catalysts have shown a promising activity to control $\mathrm{CO}$ and $\mathrm{CH}_{4}$ emissions. In the following sections, works done by various researchers are summarized.

\section{Precious metal catalysts}

The precious metal-based catalysts include PGM and gold catalysts. A lot of research has been carried out (Gelin et al. 2003; Cohn 1965; Lampert et al. 1997; Stasinska et al. 2008; Colussi et al. 2012; Hussain et al. 2015; An et al. 2014), and a comprehensive review ( $\mathrm{Li}$ and Hoflund 2003) was reported for $\mathrm{CO}$ and $\mathrm{CH}_{4}$ oxidation over precious metal catalysts. A detailed discussion is given in following sections.

PGM catalysts PGM metals are well-known oxidation catalysts for controlling $\mathrm{CO}$ and $\mathrm{CH}_{4}$ emissions. A lot of work has been done on this catalyst for various reactions due to its good catalytic activity. The supported Pd and Pt are the most commonly used for oxidation reactions. PGM metal catalysts was first-time used for CO oxidation by Cohn (1965). The performance of the catalysts for the said reactions was improved by using various supports such as alumina, magnesium, silica, etc. (Zorn et al. 2010; Pardiwala et al. 2011). The use of supports makes them economical also. It was shown that Pd-based catalysts are the most active for oxidation of $\mathrm{CO}$ and $\mathrm{CH}_{4}$ than Pt-based catalyst, as shown in Fig. 10 (Ferrandon 2001). The $\mathrm{Pd} / \gamma-\mathrm{Al}_{2} \mathrm{O}_{3}$ is found to be the most attractive catalyst for $\mathrm{CH}_{4}$ combustion which possessed the highest activity as well as good thermal stability. 


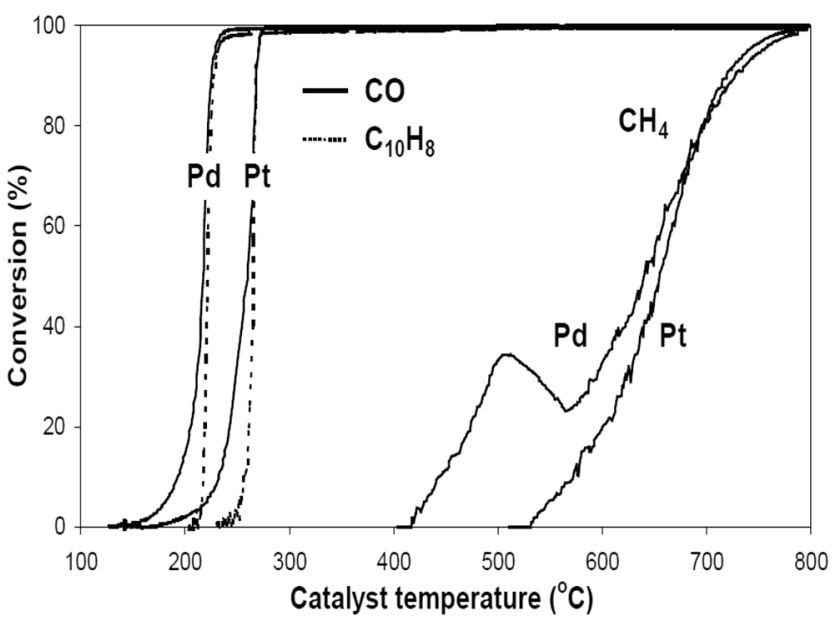

Fig. 10 Conversion of $\mathrm{CO}, \mathrm{CH}_{4}$, and $\mathrm{C}_{10} \mathrm{H}_{8}$ for $\mathrm{Al}_{2} \mathrm{O}_{3}$-supported $\mathrm{Pd}$ and Pt catalysts (Ferrandon 2001)

The $\mathrm{CH}_{4}$ oxidation is highly dependent on the active phase of the metal in the catalyst. The contradictory discussion in the literature regarding the active state of Pd catalyst (metallic Pd, $\mathrm{PdO}$, or mixed $\mathrm{Pd} / \mathrm{PdOx}$ ) is reported by many scientists (Burch et al. 1995; Lyubovsky and Pfefferle 1998; Oh and Mitchell 1994). McCarty (1995) studied that PdO is an active phase for $\mathrm{CH}_{4}$ combustion than metallic Pd. However, Kucharczyk (2015) suggested that the activity of a mixed $\mathrm{Pd} / \mathrm{PdO}$ phase was higher than $\mathrm{PdO}$ or metallic $\mathrm{Pd}$, when $\mathrm{PdO}$ were dispersed over the $\mathrm{Pd}$ surface.

Recently, $\mathrm{Pt} / \mathrm{CeO}_{2}-\mathrm{ZrO}_{2}-\mathrm{Al}_{2} \mathrm{O}_{3}$ cryogels was investigated by Osaki (2020) for $\mathrm{CO}$ and $\mathrm{CH}_{4}$ oxidation. The author reported total conversion of $\mathrm{CO}$ and $\mathrm{CH}_{4}$ over the catalyst $(\mathrm{Ce} /$ $\mathrm{Al}=1 / 3$ ) were 150 and $650{ }^{\circ} \mathrm{C}$, respectively. He also discussed the factors that influnces the catalytic activity. $\mathrm{He}$ mentioned two different conditions: (i) $\mathrm{Ce} / \mathrm{Al}<1 / 3$, the catalytic activity was decreased due to less amount of $\mathrm{Ce}$ in the catalyst which is having good oxygen storage capacity and also good distributor of $\mathrm{Pt}$ metal. (ii) $\mathrm{Ce} / \mathrm{Al}>1 / 3$, the presence of an excess amount of $\mathrm{Ce}$ is also not good because it does not provide sufficient interaction between $\mathrm{CeO}_{2}$ and $\mathrm{Pt}$ metal. Thus, optimum amount was $1 / 3$ that provides good catalytic activity but reported temperature for $\mathrm{CH}_{4}$ oxidation is still very high (Osaki 2020). The contribution of various researchers for $\mathrm{CO}$ and $\mathrm{CH}_{4}$ oxidation over PGM catalyst and its combination with non-noble metals is mentioned in Table 5. The economic reasons and limited resources of PGM-based catalytic converters have encouraged the investigation of alternative cheaper catalysts.

Gold-based catalysts The Au-based catalysts are economical than the PGM catalysts for $\mathrm{CO}$ and $\mathrm{CH}_{4}$ oxidation. It was observed that supported Au nanoparticles showed a promising activity for CO oxidation than PGM catalysts. These catalysts can completely combust $\mathrm{CO}$ at sub-ambient temperatures which was reported by Haruta et al. (1989). They also studied the effect of support for $\mathrm{CO}$ oxidation and reported the activity order as follows: $\mathrm{Au} / \mathrm{Fe}_{2} \mathrm{O}_{3}>\mathrm{Au} / \mathrm{Co}_{3} \mathrm{O}_{4}>\mathrm{Au} / \mathrm{NiO}$. Solsona et al. (2006) also studied the effect of Au supported on $\mathrm{CoO}_{x}, \mathrm{MnO}_{x}, \mathrm{CuO}, \mathrm{Fe}_{2} \mathrm{O}_{3}$, and $\mathrm{CeO}_{2}$ for $\mathrm{CO}$ oxidation and reported that the $\mathrm{Fe}_{2} \mathrm{O}_{3}$ is the best support. The result is also supported by Song et al. (1999). In practical aspect, $\mathrm{Au}$ is inert in bulk, its nanoparticles $(<5 \mathrm{~nm})$ are highly active for $\mathrm{CO}$ oxidation. The catalysts activity deos not only depend on the particle size but also other factors like preparation method and nature of support material. Qureshi and Jaseer (2018) studies the effect of support on the activity of the Au particles for $\mathrm{CO}$ oxidation (Fig. 11).

Figure 11 does not only provide the information about the effect of support but also reflects the effect of morphology and temperature as well. The performance of $\mathrm{Au} / \mathrm{SiO}_{2}$ is not good as compared with $\mathrm{Au} / \mathrm{TiO}_{2}$, but the activity of wormhole silica is quite good than hexagonal silica. Additionally, the lowtemperature preped $\mathrm{Au} / \mathrm{TiO}_{2}$ showed the best performance among all other catalysts. Generally, water affects the performance of the catalysts, but in the Au catalysts, its behavior is different which promotes the catalyst activity. Fujitani et al. (2014) studied the role of water on the activity of gold catalyst for $\mathrm{CO}$ oxidation by density functional theory calculations. The theory revealed that presence of moisture in the catalyst is advantageous such as the water maintains the cationic state of $\mathrm{Au}$ particles $\left(\mathrm{Au}^{3+} / \mathrm{Au}^{+}\right)$and also helps in the activation of $\mathrm{O}_{2}$ molecules. Recently, the geometric effect of Au nanoclusters on room-temperature $\mathrm{CO}$ oxidation discussed by Luo et al. (2020). They found that the 2D-layered Au species is more active as compared with the 3D Au nanoclusters.

While, the $\mathrm{CH}_{4}$ oxidation is also available on gold nanocatalyst, but its conversion was very low at high temperature (Choudhary et al. 2008; Solsona et al. 2006). The transition metal-supported catalysts are also efficient for $\mathrm{CH}_{4}$ oxidation (Solsona et al. 2006). Waters et al. (1994) reported the oxidation of $\mathrm{CH}_{4}$ over $\mathrm{Au}$ on various supports such as $\mathrm{Co}_{3} \mathrm{O}_{4}$, $\mathrm{NiO}, \mathrm{MnO}_{x}, \mathrm{Fe}_{2} \mathrm{O}_{3}$, and $\mathrm{CeO}_{2}$. The reported activity order for $\mathrm{CH}_{4}$ oxidation is as follows: $\mathrm{Au} / \mathrm{Co}_{3} \mathrm{O}_{4}>\mathrm{Au} / \mathrm{NiO}>\mathrm{Au} / \mathrm{MnO}_{x}$ $>\mathrm{Au} / \mathrm{Fe}_{2} \mathrm{O}_{3} \gg \mathrm{Au} / \mathrm{CeO}_{2}$ (Waters et al. 1994). However, $\mathrm{Au} /$ $\mathrm{Co}_{3} \mathrm{O}_{4}$ catalysts could be sintered at very high temperature and decomposition of $\mathrm{CO}_{3} \mathrm{O}_{4}$ is also possible. Thus, the application of the catalyst is limited for high temperature. The properties of the catalyst could be enhanced by the addition of promoters on transition metal-supported gold catalyst. Liotta et al. (2008) reported the effect of cerium addition on $\mathrm{Au} /$ $\mathrm{Co}_{3} \mathrm{O}_{4}$ catalyst for $\mathrm{CO}$ and $\mathrm{CH}_{4}$ oxidation. It was observed that the $\mathrm{Au} / \mathrm{CeO}_{2}$ showed the best performance for $\mathrm{CO}$ oxidation, while the $\mathrm{Au} / \mathrm{Co}_{3} \mathrm{O}_{4}-\mathrm{CeO}_{2}$ catalyst showed good catalytic activity for $\mathrm{CH}_{4}$ oxidation. In $\mathrm{Au} / \mathrm{Co}_{3} \mathrm{O}_{4}$, $\mathrm{Ce}$ acts as a promoter which stabilized the catalyst at high temperature $>$ $600{ }^{\circ} \mathrm{C}$ and maintain its activity for $\mathrm{CH}_{4}$ oxidation (Liotta et al. 2008). The doping of little amount of PGM catalyst in the catalyst could lower down the reaction temperature for $\mathrm{CO}$ 
Table 5 Literature review at a glimpse for PGM catalyst for $\mathrm{CO}$ and $\mathrm{CH}_{4}$ oxidation

\begin{tabular}{|c|c|c|c|}
\hline Ref. & Catalyst & Experimental parameters & Remarks \\
\hline \multicolumn{4}{|l|}{ CO oxidation } \\
\hline Zorn et al. (2010) & $\mathrm{Pd}-\mathrm{Al}_{2} \mathrm{O}_{3}$, incipient & $\begin{array}{l}50 \text { mbar } \mathrm{CO} ; 50 \mathrm{mbar}_{2} ; \text { turnover } \\
\text { frequency, } 1 \mathrm{~s}^{-1}\end{array}$ & 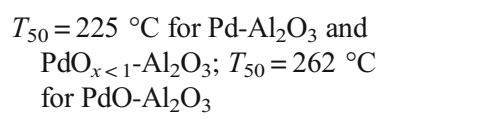 \\
\hline Zhang et al. (2014) & $\mathrm{Pd} / \mathrm{Al}_{2} \mathrm{O}_{3}$ & $\begin{array}{l}20 \text { mg catalyst wt.; } 0.02 \% \mathrm{CO} \text { and } \\
20 \% \mathrm{O}_{2} \text { balanced with } \mathrm{N}_{2} \text {; total } \\
\text { flow rate, } 100 \mathrm{ml} \mathrm{min}^{-1} ; \mathrm{GHSV} \\
9000-60,000 \mathrm{~h}^{-1}\end{array}$ & $T_{100}=92{ }^{\circ} \mathrm{C}$ \\
\hline An et al. (2014) & $\mathrm{Pt} / \mathrm{Al}_{2} \mathrm{O}_{3}$ & 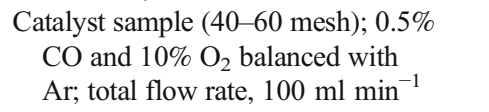 & $\begin{array}{l}T_{100}=110{ }^{\circ} \mathrm{C} \mathrm{Pt} / \mathrm{Al}_{2} \mathrm{O}_{3} \text { calcined } \\
\quad \text { at } 300{ }^{\circ} \mathrm{C}\end{array}$ \\
\hline \multicolumn{4}{|l|}{$\mathrm{CH}_{4}$ oxidation } \\
\hline Gelin et al. (2003) & $\mathrm{Pd} / \mathrm{CoAl}_{2} \mathrm{O}_{4} / \mathrm{Al}_{2} \mathrm{O}_{3}$ & $\begin{array}{l}200 \mathrm{mg} \text { catalyst wt.; } 0.4 \% \mathrm{CH}_{4} \text {; } \\
10 \% \mathrm{O}_{2} \text { balanced with } \mathrm{He} \text {; total } \\
\text { flow rate, } 100 \mathrm{ml} \mathrm{min}^{-1}\end{array}$ & $\begin{array}{l}\text { PdCoAl-GD > PdAl-I > PdCoAl-SI; } \\
\quad T_{10}=266{ }^{\circ} \mathrm{C} \text { for PdCoAl-GD }\end{array}$ \\
\hline Gelin et al. (2003) & $\mathrm{Pd} / \mathrm{Al}_{2} \mathrm{O}_{3}$ and $\mathrm{Pt} / \mathrm{Al}_{2} \mathrm{O}_{3}$ & $\begin{array}{l}20 \mathrm{mg} \text { catalyst wt.; } 0.2 \% \mathrm{CH}_{4} ; 5 \% \\
\mathrm{O}_{2} \text { in He; total flow rate, } \\
360 \mathrm{ml} \mathrm{min}^{-1} ; \mathrm{GHSV}, 20,000 \mathrm{~h}^{-1}\end{array}$ & $T_{50}=320^{\circ} \mathrm{C}$ for $\mathrm{Pd} / \mathrm{Al}_{2} \mathrm{O}_{3} ; T_{50}=425^{\circ} \mathrm{C}$ \\
\hline Seeburg et al. (2018) & $\begin{array}{l}\mathrm{Pd} / \mathrm{MeO}_{x} \\
\quad\left(\mathrm{Me}=\mathrm{Fe}_{2} \mathrm{O}_{3}, \mathrm{Co}_{3} \mathrm{O}_{4}, \mathrm{NiO}\right)\end{array}$ & $\begin{array}{l}200 \mathrm{mg} \text { catalyst wt.; feed mixture; } \\
\mathrm{CH}_{4}: \mathrm{O}_{2}: \mathrm{N}_{2}=1: 18: 81 \text {; total flow } \\
\text { rate, } 75 \mathrm{ml} \mathrm{min}{ }^{-1} ; \mathrm{GHSV}, 22,500 \mathrm{~h}^{-1}\end{array}$ & $\begin{array}{l}T_{100}=450{ }^{\circ} \mathrm{C} \text { for } \mathrm{NiO} ; T_{100}=500{ }^{\circ} \mathrm{C} \\
\mathrm{Co}_{3} \mathrm{O}_{4} \text { and } \mathrm{Fe}_{2} \mathrm{O}_{3}\end{array}$ \\
\hline \multicolumn{4}{|l|}{$\mathrm{CO}-\mathrm{CH}_{4}$ oxidation } \\
\hline Osaki (2020) & $\mathrm{Pt} / \mathrm{CeO}_{2}{ }^{-} \mathrm{ZrO}_{2}^{-} \mathrm{Al}_{2} \mathrm{O}_{3}$ & $\begin{array}{l}\mathrm{CO} \text { oxidation, } 15 \mathrm{mg} \text { catalyst wt.; } \\
\text { total flow rate, } 50 \mathrm{ml} \mathrm{min}{ }^{-1} ; \mathrm{CH}_{4} \\
\text { oxidation, } 100 \mathrm{mg} \text { catalyst wt.; } \\
\text { total flow rate, } 100 \mathrm{ml} \mathrm{min}^{-1}\end{array}$ & $\begin{array}{l}\mathrm{CO} \text { oxidation, } T_{100}=150{ }^{\circ} \mathrm{C} ; \mathrm{CH}_{4} \\
\quad \text { oxidation, } T_{100}=650{ }^{\circ} \mathrm{C}\end{array}$ \\
\hline
\end{tabular}

oxidation, for example, the doping of $\mathrm{Pt}$ in $\mathrm{Au} / \mathrm{Co}_{3} \mathrm{O}_{4}$ catalyst could lower down the temperature of up to $50{ }^{\circ} \mathrm{C}$ for $\mathrm{CO}$ oxidation due to a strong interaction of $\mathrm{Pt}$ with $\mathrm{Au}$ and $\mathrm{Co}_{3} \mathrm{O}_{4}$ (Miao and Deng 2001).

The performance of the catalysts also depends on the preparation methods which affects the size of the catalysts. Further, Ivanova et al. (2006) synthesized the $\mathrm{Au} / \gamma-\mathrm{Al}_{2} \mathrm{O}_{3}$ catalyst by two different methods such as direct anionic exchange and deposition-precipitation. The authors reported that direct anionic exchange method is better than precipitation-

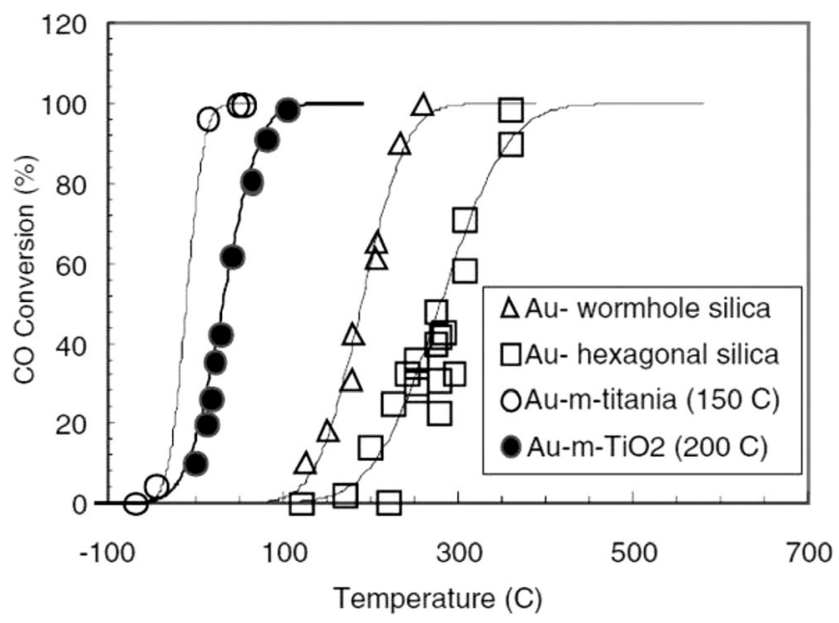

Fig. 11 Effect of support for CO oxidation (Qureshi and Jaseer 2018) deposition (Ivanova et al. 2006). However, the gold catalyst is temperature sensitive and not favorable at high temperature $1000{ }^{\circ} \mathrm{C}$. Thus, the high-temperature stable and economical catalysts were of a major concern for automotive emission control. The glimpse of literature or oxidation of $\mathrm{CO}$ and $\mathrm{CH}_{4}$ over precious metal catalysts is mentioned in Table 6.

\section{Non-noble metal catalysts}

The rare availability and high cost encouraged for the search of alternative cheaper transition metal catalysts. So, the researchers found the different transition metal catalysts for vehicular emission control and categorized as perovskite, hydrotalcite, mixed metal oxides, and spinel (Heo et al. 2014; Tao et al. 2015; Trivedi and Prasad 2016; Trivedi and Prasad 2018; Xie et al. 2009). In the field of automotive emission control, few Ph.D. degrees (Ferrandon 2001; Iablokov and Kruse 2011; Kucharczyk 2015) were given by various universities and several comprehensive reviews (Liotta et al. 2013; Mankidy et al. 2014; Prasad and Singh 2012; Rattan and Kumar 2014) were reported for $\mathrm{CO}$ and $\mathrm{CH}_{4}$ oxidation. The comprehensive literature of transition metal oxides for $\mathrm{CO}$ and $\mathrm{CH}_{4}$ oxidation is described in following sections:

Perovskite catalysts The general stoichiometry structure of perovskite is $\mathrm{ABO}_{3}$, where " $\mathrm{A}$ " and " $\mathrm{B}$ " are divalent and 
Table 6 Literature at a glance for $\mathrm{CO}$ and $\mathrm{CH}_{4}$ oxidation over $\mathrm{Au}$ catalysts

\begin{tabular}{|c|c|c|c|}
\hline Ref. & Catalyst & Experimental parameters & Remarks \\
\hline \multicolumn{4}{|l|}{$\mathrm{CO}$ oxidation } \\
\hline Haruta et al. (1989) & $\mathrm{Au} / \mathrm{Fe}_{2} \mathrm{O}_{3}, \mathrm{Au} / \mathrm{Co}_{3} \mathrm{O}_{4}, \mathrm{Au} / \mathrm{NiO}$ & $\begin{array}{l}200 \mathrm{mg} \text { catalyst wt.; } 1 \% \mathrm{CO} \text { balanced } \\
\text { with air; total flow rate, } 66 \mathrm{ml} \mathrm{min}^{-1}\end{array}$ & $\begin{array}{l}T_{100} \text { for } \mathrm{Au} / \mathrm{Fe}_{2} \mathrm{O}_{3}=-70{ }^{\circ} \mathrm{C} ; \\
\quad \text { activity order, } \mathrm{Fe}_{2} \mathrm{O}_{3}>\mathrm{Co}_{3} \mathrm{O}_{4}>\mathrm{NiO}\end{array}$ \\
\hline Solsona et al. (2006) & $\begin{array}{l}\text { Au supported on } \mathrm{CoO}_{x}, \mathrm{MnO}_{x} \\
\qquad \mathrm{CuO}, \mathrm{Fe}_{2} \mathrm{O}_{3}, \mathrm{CeO}_{2}\end{array}$ & $\begin{array}{l}50 \text { mg catalyst wt.; } 0.5 \% \mathrm{CO} \text { in air; } \\
\text { total flow rate, } 22.5 \mathrm{ml} \mathrm{min}^{-1}\end{array}$ & $T_{91}$ for $\mathrm{Au} / \mathrm{Fe}_{2} \mathrm{O}_{3}=25{ }^{\circ} \mathrm{C}$ \\
\hline Liotta et al. (2008) & $\begin{array}{l}\text { Au supported on } \mathrm{Co}_{3} \mathrm{O}_{4}, \mathrm{CeO}_{2} \\
\mathrm{Co}_{3} \mathrm{O}_{4}-\mathrm{CeO}_{2}\end{array}$ & $\begin{array}{l}50 \text { mg catalyst wt.; } 1 \% \mathrm{CO} ; 1 \% \mathrm{O}_{2} \\
\text { balance by He; total flow rate, } \\
50 \mathrm{ml} \mathrm{min}^{-1}\end{array}$ & $\begin{array}{l}T_{50} \text { for } \mathrm{Au} / \mathrm{CeO}_{2}=92{ }^{\circ} \mathrm{C} \text {; activity } \\
\quad \text { order, } \mathrm{CeO}_{2}>\mathrm{Co}_{3} \mathrm{O}_{4}-\mathrm{CeO}_{2}>\mathrm{Co}_{3} \mathrm{O}_{4}\end{array}$ \\
\hline Song et al. (1999) & $\mathrm{Au}$ supported on $\mathrm{FeO}_{x}$ & $\begin{array}{l}50 \mathrm{mg} \text { catalyst wt.; } 1 \% \mathrm{CO} \text { balanced } \\
\text { by } \mathrm{N}_{2} \text {; total flow rate, } 60 \mathrm{ml} \mathrm{min}^{-1} \text {; } \\
\text { space velocity, } 80,000 \mathrm{~mL} \mathrm{~h}^{-1} \mathrm{gcat}^{-1}\end{array}$ & $T_{100}=85^{\circ} \mathrm{C}$ \\
\hline Qureshi and Jaseer (2018) & $\mathrm{Au}$ supported on $\mathrm{SiO}_{2}$ and $\mathrm{TiO}_{2}$ & - & Activity order, $\mathrm{Au} / \mathrm{TiO}_{2}>\mathrm{Au} / \mathrm{SiO}_{2}$ \\
\hline \multicolumn{4}{|l|}{$\mathrm{CH}_{4}$ oxidation } \\
\hline Miao and Deng (2001) & Pt-doped $\mathrm{Au} / \mathrm{Co}_{3} \mathrm{O}_{4}$ & $\begin{array}{l}10 \mathrm{mg} \text { catalyst wt.; } 1 \% \mathrm{CH}_{4} ; 5 \% \mathrm{O}_{2} ; \\
\text { and rest } \mathrm{N}_{2} ; \mathrm{GHSV}, 10,000 \mathrm{~h}^{-1}\end{array}$ & $\mathrm{Pt}-\mathrm{Au} / \mathrm{Co}_{3} \mathrm{O}_{4}, T_{100}$ decreased to $50{ }^{\circ} \mathrm{C}$ \\
\hline Solsona et al. (2006) & $\begin{array}{l}\text { Au supported on } \mathrm{CoO}_{x}, \mathrm{MnO}_{x} \text {, } \\
\qquad \mathrm{CuO}, \mathrm{Fe}_{2} \mathrm{O}_{3}, \mathrm{CeO}_{2}\end{array}$ & 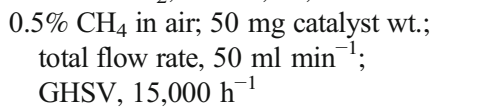 & $T_{100}$ for $\mathrm{Au} / \mathrm{CoO}_{x}=350^{\circ} \mathrm{C}$ \\
\hline Liotta et al. (2008) & $\begin{array}{l}\text { Au supported on } \mathrm{Co}_{3} \mathrm{O}_{4}, \mathrm{CeO}_{2} \\
\qquad \mathrm{Co}_{3} \mathrm{O}_{4}-\mathrm{CeO}_{2}\end{array}$ & $\begin{array}{l}50 \mathrm{mg} \text { catalyst wt.; } 0.3 \% \mathrm{CH}_{4} ; 2.4 \% \\
\mathrm{O}_{2} \text { balance by } \mathrm{He} \text {; total flow rate, } \\
50 \mathrm{ml} \mathrm{min}\end{array}$ & $T_{50}$ for $\mathrm{Au} / \mathrm{Co}_{3} \mathrm{O}_{4}-\mathrm{CeO}_{2}=405^{\circ} \mathrm{C}$ \\
\hline
\end{tabular}

tetravalent cations of very different sizes; $\mathrm{O}$ is an anion bonds to both cations, as shown in Fig. 12.

Perovskite oxides build up by incorporation of A cations into $\mathrm{BO}_{6}$ octahedron, where $\mathrm{A}$ is rare earth ( $\left.\mathrm{La}, \mathrm{Ce}, \mathrm{Pr}, \mathrm{Nd}\right)$, alkali, or alkaline earth metal (Cs, Sr, Ba, Ca, $\mathrm{Ra}$ ) of larger ions (radius of $\mathrm{A} \sim 0.90 \AA$ ) and $\mathrm{B}$ site was consisted of various transition metal cations with relatively smaller radius (radius of B $0.51 \AA$ ) (Forni and Rossetti 2002; Labhsetwar et al. 2006; Shinjoh 2006). Many perovskites can be designed by the partial substitution of A and B cations with other heterovalent cation which induces the structural distortions and/or B

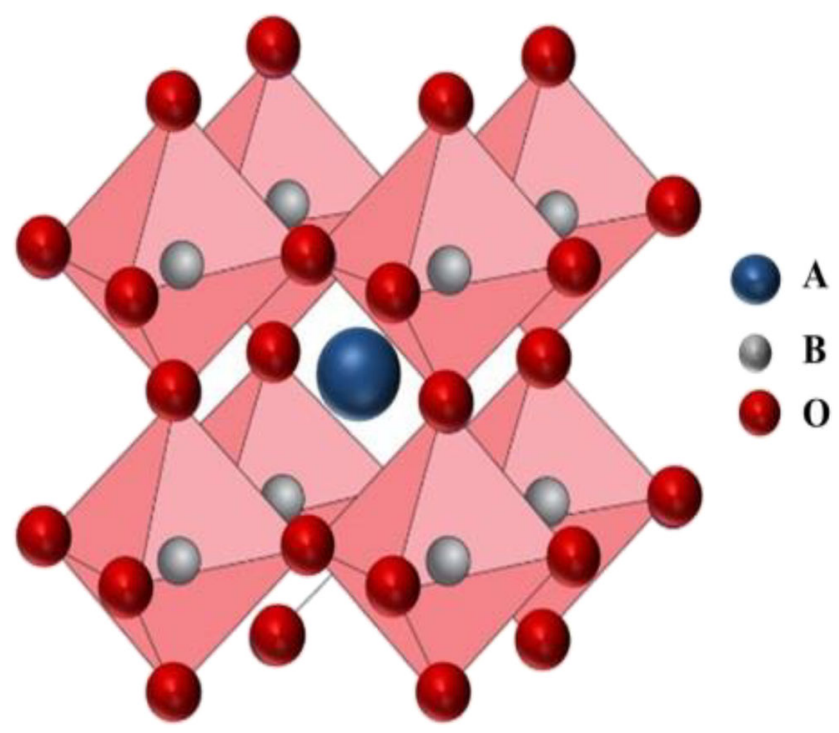

Fig. 12 Structure of perovskite catalyst site valence transformations and altering their physiochemical properties for various applications with improved activity (Alifanti et al. 2007; Ciambelli et al. 2001). The perovskite catalysts are thermally stable, having excellent redox properties, good mechanical strength, low cost, and large variety in comparison with the other oxides. Limited work is available in the literature for $\mathrm{CO}$ and $\mathrm{CH}_{4}$ oxidation under the same experimental condition over perovskite catalysts (Arandiyan 2015; Kucharczyk 2015; Liu et al. 2013; Najjar et al. 2011; Wang et al. 2012).

The oxidation of $\mathrm{CO}$ and $\mathrm{CH}_{4}$ over $\mathrm{LaMnO}_{3}$ under the same experimental condition was reported by several authors (Kucharczyk 2015; Machocki et al. 2004; Seiyama 1992). Kucharczyk (2015) studied oxidation of $\mathrm{CO}$ over $\mathrm{LaMnO}_{3}$ and found that a high temperature of $295{ }^{\circ} \mathrm{C}$ is required for the complete oxidation reaction. The performance of the perovskite catalyst could be improved by substitution of $\mathrm{A}$ and $\mathrm{B}$ sites by small amount of noble metal for the said reaction. Thus, the authors observed that the substitution on A site in the perovskite with small amount ( $\mathrm{Pd}, 0.05-0.2 \mathrm{wt} . \%)$ of noble metal improves the activity of the catalyst for $\mathrm{CO}$ oxidation than the substitution of Pd metal on B site of perovskite. The substitution decreased the total oxidation temperature up to $45^{\circ} \mathrm{C}$ (Kucharczyk 2015). While, the complete $\mathrm{CH}_{4}$ oxidation over $\mathrm{LaMnO}_{3}$ was also reported by Machocki et al. (2004). Further, modification in $\mathrm{LaMnO}_{3}$ catalyst by Ag was done to improve the performance of the catalyst for $\mathrm{CH}_{4}$ oxidation. The activity order of the catalysts modified by Ag for the same reaction was as follows: $\mathrm{La}_{0.7} \mathrm{Ag}_{0.3} \mathrm{MnO}_{3}>$ $\mathrm{La}_{0.9} \mathrm{Ag}_{0.1} \mathrm{MnO}_{3}>\mathrm{LaMnO}_{3}$. However, the reported total 
oxidation temperature $\left(>400{ }^{\circ} \mathrm{C}\right)$ for $\mathrm{CO}$ and $\mathrm{CH}_{4}$ over perovskite is relatively high than the other metal oxides (Wei et al. 2010). The perovskite is prominent for soot oxidation (Mishra and Prasad 2015), but it is not suited for $\mathrm{CH}_{4}$ oxidation as well (Chen et al. 2010; Machocki et al. 2004; Wei et al. 2010) due to their low surface area. The literature survey at a glance over perovskite catalyst for said reaction is mentioned in Table 7.

Hydrotalcite Hydrotalcite (HT) and their compounds (HTlcs), called layered double hydroxides which is represented by general compound $\mathrm{Mg}_{6} \mathrm{Al}_{2}\left(\mathrm{CO}_{3}\right)(\mathrm{OH})_{16} \cdot 4\left(\mathrm{H}_{2} \mathrm{O}\right)$. Generally, HTlcs are denoted by double-layered hydrotalcite (LDH). The chemical expression of these material is $\left[\mathrm{M}(\Pi)_{1-x}\right.$ $\left.\mathrm{M}(\amalg)_{x}(\mathrm{OH})_{2}\right]^{x+}\left[\left(\mathrm{A}^{n-}\right)_{x / n} \cdot \mathrm{mH}_{2} \mathrm{O}\right]^{x-}$, where $\mathrm{M}(\Pi)$ represents any divalent metal cation, $\mathrm{M}(\amalg)$ any trivalent metal cation, and $\mathrm{A}^{n-}$ an anion; the value of $x$ is equal to the molar ratio of $\mathrm{M}(\Pi) /(\mathrm{M}(\Pi)+\mathrm{M}(\amalg))$ which ranges between 0.2 and 0.4 (Vaccari 1998). The structure of hydrotalcite catalyst is shown in Fig. 13.

Recently, HTlcs have been receiving a considerable attention as heterogeneous catalyst due to their high surface area and good catalytic activity (Cavani et al. 1991; Martínez-Lozano et al. 2007; Takehira et al. 2004). Mokhtar et al. (2010) prepared spinel catalyst via CoMnMgAl hydrotalcite precursor for $\mathrm{CO}$ oxidation. The authors found that catalyst with $\mathrm{Co} / \mathrm{Mn}=4$ showed the best catalytic performance for complete $\mathrm{CO}$ oxidation at $160{ }^{\circ} \mathrm{C}$. Genty et al. (2015) investigated $\mathrm{X}_{6} \mathrm{Al}_{2} \mathrm{HT}$ hydrotalcite $(\mathrm{X}=\mathrm{Fe}, \mathrm{Cu}, \mathrm{Zn}, \mathrm{Ni}, \mathrm{Co}, \mathrm{Mn}$, or $\mathrm{Mg}$ ) precursor for the same reaction and found that $\mathrm{X}_{6} \mathrm{Al}_{2}$ nano-oxides is the best one, but the maximum conversion was limited to $50 \%$ at very high temperature of $249^{\circ} \mathrm{C}$. Further, multi-oxide catalysts of $\mathrm{Zn}, \mathrm{Cu}$, and Ti with different ratios were obtained from $\mathrm{LDH}$ precursors for $\mathrm{CO}$ oxidation and a maximum conversion of $95 \%$ at $275{ }^{\circ} \mathrm{C}$ was reported. The formation of different phases was confirmed by XRD analysis.
The $\mathrm{CH}_{4}$ oxidation over hydrotalcite catalysts was also studied by some researchers. Cheng et al. (2008) studied $\mathrm{CH}_{4}$ combustion over $\mathrm{Cu}-\mathrm{Co} / \mathrm{X}-\mathrm{Al}$ (X: $\mathrm{Fe}, \mathrm{Mn}, \mathrm{La}, \mathrm{Ce}$ ) hydrotalcite-like compounds and observed total oxidation at $496{ }^{\circ} \mathrm{C}$. The $\mathrm{Co}_{x} \mathrm{Mg}_{3-x} / \mathrm{Al}$ oxides were produced by calcination of $\mathrm{Co}_{x} \mathrm{Mg}_{3-x} / \mathrm{Al}$ hydrotalcite precursor $(x=0.0,0.5,1.0$, $1.5,2.0,2.5$, and 3.0 ) at $800{ }^{\circ} \mathrm{C}$ by Jiang et al. (2010). The activity, thermal stability, and homogeneity of the catalyst markedly depend on the concentration of Co in the hydrotalcite. They found $90 \%$ conversion at $600{ }^{\circ} \mathrm{C}$ over 1.5 CoMgAlO. Recently, Liu et al. $(2013,2014)$ observed the $\mathrm{CH}_{4}$ oxidation by utilizing $\mathrm{Co}_{x} \mathrm{Mg}_{6-x} \mathrm{Mn}_{2} \mathrm{LDO}$ as a catalyst. The maximum conversion was limited to $90 \%<495{ }^{\circ} \mathrm{C}$ over $\mathrm{Co}_{4.5} \mathrm{Mg}_{1.5} \mathrm{Mn}_{2} \mathrm{LDO}$ (Saber and Zaki 2014). Literature at a sight for $\mathrm{CO}$ and $\mathrm{CH}_{4}$ oxidation over hydrotalcite catalyst is presented in Table 8.

With the aforementioned background, it is concluded that LDH showed good catalytic performance for $\mathrm{CO}$ and $\mathrm{CH}_{4}$ combustion. The $\mathrm{Co}-\mathrm{Mn}-\mathrm{Mg}-\mathrm{Al}$ and $\mathrm{Cu}-\mathrm{Co} / \mathrm{X}-\mathrm{Al}(\mathrm{X}=\mathrm{Fe}$, $\mathrm{Mn}, \mathrm{La}, \mathrm{Ce}$ ) catalysts showed the total oxidation of $\mathrm{CO}$ and $\mathrm{CH}_{4}$, respectively. However, the temperature for $\mathrm{CH}_{4}$ oxidation is relativity higher than $\mathrm{Co}-\mathrm{Mn}$-mixed oxide and spinel catalysts as reported in the literature.

Mixed oxides The mixed metal oxides showed the good catalytic performance in comparison with individual metal oxides for the said reaction (Ferrandon 2001). A lot of literature is available for $\mathrm{CO}$ oxidation, while the studies on total $\mathrm{CH}_{4}$ combustion are also limited over mixed oxides (BiabaniRavandi and Rezaei 2012; Li et al. 2009). Ferrandon (2001) studied the oxidation of both $\mathrm{CO}$ and $\mathrm{CH}_{4}$ over supported mixed metal oxides in his thesis work. The researchers synthesized the $\mathrm{Al}_{2} \mathrm{O}_{3}$-supported metal oxides $(\mathrm{Cu}, \mathrm{Mn}, \mathrm{Fe}, \mathrm{Co}$, and $\mathrm{Ni}$ ) by incipient wetness impregnation methods and checked their performance for $\mathrm{CO}, \mathrm{CH}_{4}$, and $\mathrm{C}_{10} \mathrm{H}_{8}$ oxidation (Ferrandon 2001). Generally, $\mathrm{CuO}$ seems to have a high

Table 7 Literature review at a glance of perovskite catalysts for $\mathrm{CO}$ and $\mathrm{CH}_{4}$ oxidation

\begin{tabular}{|c|c|c|c|}
\hline Ref. & Catalyst & Experimental parameters & Remarks \\
\hline \multicolumn{4}{|l|}{ CO oxidation } \\
\hline Song et al. (1999) & $\mathrm{La}_{1-x} \mathrm{M}_{x} \mathrm{MnO}_{3}(\mathrm{M}=\mathrm{Ag}, \mathrm{Sr}, \mathrm{Ce}, \mathrm{La})$ & $\begin{array}{l}250 \text { mg catalyst wt.; } 1 \% \mathrm{CO} \\
\text { balanced with air; total flow } \\
\text { rate, } 66 \mathrm{ml} \mathrm{min}^{-1} ; \mathrm{GHSV} \\
10,000 \mathrm{~h}^{-1}\end{array}$ & $T_{100}=97^{\circ} \mathrm{C}$ over $\mathrm{La}_{0.7} \mathrm{Ag}_{0.3} \mathrm{MnO}_{3}$ \\
\hline Kucharczyk (2015) & $\begin{array}{l}\mathrm{La}_{1-x} \mathrm{Pd}_{x} \mathrm{MnO}_{3}(x=0.05-0.2) \\
\mathrm{LaMn}_{1-y} \mathrm{Pd}_{\mathrm{y}} \mathrm{O}_{3}(y=0.1-0.15)\end{array}$ & 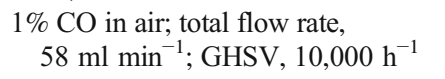 & $T_{100}=250{ }^{\circ} \mathrm{C}$ over $\mathrm{La}_{0.85} \mathrm{Pd}_{0.15} \mathrm{MnO}_{3}$ \\
\hline \multicolumn{4}{|l|}{$\mathrm{CH}_{4}$ oxidation } \\
\hline Song et al. (2014) & $\mathrm{La}_{1-x} \mathrm{M}_{x} \mathrm{MnO}_{3}(\mathrm{M}=\mathrm{Ag}, \mathrm{Sr}, \mathrm{Ce}, \mathrm{La})$ & 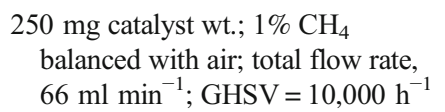 & $T_{100}=552{ }^{\circ} \mathrm{C}$ over $\mathrm{La}_{0.7} \mathrm{Ag}_{0.3} \mathrm{MnO}_{3}$ \\
\hline Machocki et al. (2004) & $\mathrm{La}_{1-x} \mathrm{Ag}_{x} \mathrm{MnO}_{3}(x=0,0.1,0.3)$ & 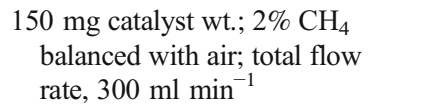 & $\begin{array}{l}T_{100}>500{ }^{\circ} \mathrm{C} ; \text { activity order } \\
\mathrm{La}_{0.7} \mathrm{Ag}_{0.3} \mathrm{MnO}_{3}>\mathrm{La}_{0.9} \mathrm{Ag}_{0.1} \\
\mathrm{MnO}_{3}>\mathrm{LaMnO}_{3}\end{array}$ \\
\hline
\end{tabular}


Fig. 13 Structure of hydrotalcite catalyst

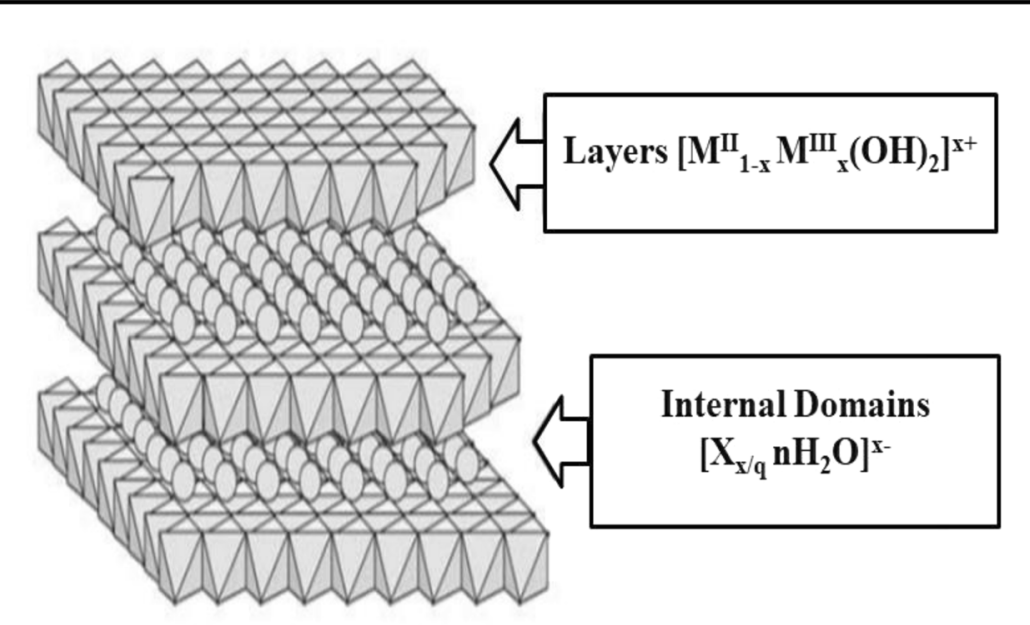

activity than $\mathrm{MnO}_{x}$ for the said reaction (Grisel and Nieuwenhuys 2001). The comparison of supported metal oxides for $\mathrm{CO}$ and $\mathrm{CH}_{4}$ oxidation is shown in Fig. 14.

It can be clearly seen from the figure that $\mathrm{Ni}$ possesses poor activity for the reaction. The activity order of metals is as follows: $\mathrm{Cu}>\mathrm{Mn}>\mathrm{Fe}>\mathrm{Co}>\mathrm{Ni}$. Further, the combination of ceria with different $\mathrm{MO}_{x}(\mathrm{M}=\mathrm{Cu}, \mathrm{Mn}, \mathrm{Fe}, \mathrm{Co}$, and Ni) was tested for $\mathrm{CO}$ and $\mathrm{CH}_{4}$ oxidation by Dongsheng et al. (2010). The authors reported the effect of $\mathrm{H}_{2} \mathrm{O}$ vapor on the performance of the catalysts. The light-off temperatures $\left(T_{50}\right)$ for $\mathrm{CO}$ and $\mathrm{CH}_{4}$ oxidation were 150 and $514{ }^{\circ} \mathrm{C}$, respectively, over the best catalyst $\mathrm{Ce}_{0.9} \mathrm{Co}_{0.1} \mathrm{O}_{2-\delta}$ composition. In the presence of $\mathrm{H}_{2} \mathrm{O}$ vapor, light off temperatures for $\mathrm{CO}$ and $\mathrm{CH}_{4}$ were raised to 17 and $5{ }^{\circ} \mathrm{C}$ which results the deactivation of the catalysts (Dongsheng et al. 2010). Literature review at glance of Co-Mn-mixed oxides is presented in Table 9.

From the aforementioned background, it was observed that the oxidation temperature for $\mathrm{CH}_{4}$ oxidation is very high in comparison with $\mathrm{CO}$. Till now, the lowest reported temperature for $\mathrm{CH}_{4}$ oxidation over Co-Mn-mixed oxides (Co:Mn = $5: 1$ ) was $340{ }^{\circ} \mathrm{C}$ for maximum $90 \%$ conversion ( $\mathrm{Li}$ et al. 2009). In the mixed oxide catalysts, the insertion of $\mathrm{Mn}$ in $\mathrm{Co}_{3} \mathrm{O}_{4}$ improves the activity of reactive ion present in octahedral site which assist dihydroxylation steps (Li et al. 2009).

Table 8 Literature review at a glance of hydrotalcite catalysts for $\mathrm{CO}$ and $\mathrm{CH}_{4}$ oxidation (GHSV, $T_{100}, T_{50}, T_{90 \sim 95}$ )

\begin{tabular}{|c|c|c|c|}
\hline Ref. & Catalyst & Experimental parameters & Remarks \\
\hline \multicolumn{4}{|l|}{$\mathrm{CO}$ oxidation } \\
\hline Mokhtar et al. (2010) & $\begin{array}{l}\mathrm{Co}-\mathrm{Mn}-\mathrm{Mg}-\mathrm{Al} \text { mixed oxide, } \\
\mathrm{Co} / \mathrm{Mn}=2 \text { and } 4, \mathrm{Mg} / \mathrm{Al}=2\end{array}$ & $\begin{array}{l}100 \mathrm{mg} \text { catalyst wt.; } 3 \% \mathrm{CO}, 6 \% \mathrm{O}_{2} \\
\text { in helium, total flow rate, } \\
10 \mathrm{ml} \mathrm{min}^{-1} ; \mathrm{GHSV}, 30,000 \mathrm{~h}^{-1}\end{array}$ & $\begin{array}{l}\text { Catalyst } \mathrm{Co} / \mathrm{Mn}=4 \text { and calcined } \\
\text { at } 500{ }^{\circ} \mathrm{C}, T_{100}=160{ }^{\circ} \mathrm{C}\end{array}$ \\
\hline Genty et al. (2015) & $\begin{array}{l}\mathrm{X}_{6} \mathrm{Al}_{2} \mathrm{HT}(\mathrm{X}=\mathrm{Fe}, \mathrm{Cu}, \mathrm{Zn}, \mathrm{Ni}, \\
\quad \mathrm{Co}, \mathrm{Mn}, \mathrm{Mg})\end{array}$ & $\begin{array}{l}100 \mathrm{mg} \text { catalyst wt.; } 0.05 \% \mathrm{CO} \\
\text { and } 10 \% \mathrm{O}_{2} \text { balanced with } \mathrm{N}_{2} \\
\text { total flow rate, } 100 \mathrm{ml} \mathrm{min}^{-1}\end{array}$ & $\mathrm{Mn}_{6} \mathrm{Al}_{2} \mathrm{HT}$ at $500{ }^{\circ} \mathrm{C}, T_{50}=249{ }^{\circ} \mathrm{C}$ over \\
\hline Saber and Zaki (2014) & $\begin{array}{c}\mathrm{Zn}-\mathrm{Cu}-\mathrm{Ti} \text { hydroxides, } \\
\mathrm{Zn} / \mathrm{Cu}=0.5,1,2\end{array}$ & $\begin{array}{l}100 \mathrm{mg} \text { catalyst wt., total flow } \\
\text { rate: } 125 \mathrm{ml} \mathrm{min}^{-1}\end{array}$ & $\mathrm{Zn}_{4} \mathrm{Cu}_{4} \mathrm{Ti}$ at $500{ }^{\circ} \mathrm{C}, T_{90 \sim 95}=275^{\circ} \mathrm{C}$ \\
\hline \multicolumn{4}{|l|}{$\mathrm{CH}_{4}$ oxidation } \\
\hline Cheng et al. (2008) & $\begin{array}{l}\mathrm{Cu}-\mathrm{Co} / \mathrm{X}-\mathrm{Al}(\mathrm{X}=\mathrm{Fe}, \mathrm{Mn} \\
\mathrm{La}, \mathrm{Ce})\end{array}$ & $\begin{array}{l}500 \mathrm{mg} \text { catalyst wt. } \mathrm{CH}_{4} \text { :air } \\
\text { volume ratio }=1: 99 ; \text { total } \\
\text { flow rate, } 400 \mathrm{ml} \mathrm{min}^{-1} ; \\
\text { GHSV, } 60,000 \mathrm{~h}^{-1}\end{array}$ & $\mathrm{Cu}_{1} \mathrm{Co}_{2} / \mathrm{Mn}_{0.2} \mathrm{Al}_{0.8}, T_{100}=496{ }^{\circ} \mathrm{C}$ \\
\hline Jiang et al. (2010) & $\begin{array}{l}\mathrm{Co}_{x} \mathrm{Mg}_{3-x} / \mathrm{Al}(x=0.0,0.5,1.0 \\
\quad 1.5,2.0,2.5,3.0) \\
\text { precipitation }\end{array}$ & $\begin{array}{l}500 \mathrm{mg} \text { catalyst wt.; } \mathrm{CH}_{4} \text { :air } \\
\text { vol. ratio }=1: 99 \text {; total flow } \\
\text { rate, } 400 \mathrm{ml} \mathrm{min}{ }^{-1} ; \mathrm{GHSV} \\
50,000 \mathrm{~h}^{-1}\end{array}$ & $1.5 \mathrm{CoMgAlO}, T_{90}=600^{\circ} \mathrm{C}$ \\
\hline Liu et al. (2014) & $\mathrm{Co}_{x} \mathrm{Mg}_{6-x} \mathrm{Mn}_{2} \mathrm{LDH}$ & $\begin{array}{l}500 \mathrm{mg} \text { catalyst wt.; } \\
\mathrm{CH}_{4}: \mathrm{O}_{2}: \mathrm{N}_{2}=1.6: 16: 144 \text {; total } \\
\text { flow rate, } 160 \mathrm{ml} \mathrm{min}^{-1} \text {; } \\
\text { GHSV }, 25,000 \mathrm{~h}^{-1}\end{array}$ & $\begin{array}{l}\text { Activity order: } \mathrm{Co}_{4.5} \mathrm{Mg}_{1.5} \mathrm{Mn}_{2} \mathrm{LDO}> \\
\mathrm{Co}_{6} \mathrm{Mn}_{2} \mathrm{LDO}>\mathrm{Co}_{3} \mathrm{Mg}_{3} \mathrm{Mn}_{2} \mathrm{LDO}> \\
\mathrm{Co}_{1.5} \mathrm{Mg}_{4.5} \mathrm{Mn}_{2} \mathrm{LDO}\end{array}$ \\
\hline
\end{tabular}




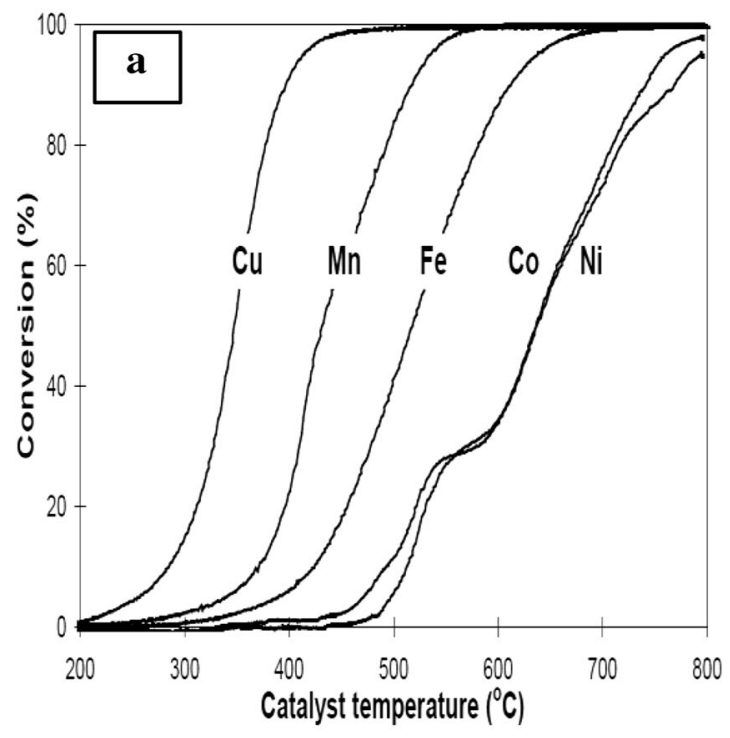

Fig. 14 Conversion of $\mathbf{a} \mathrm{CO}$ and $\mathbf{b} \mathrm{CH}_{4}$ over supported metal oxides

Spinel catalysts The spinel comprises a large group of ternary compounds with general formula, $\mathrm{AB}_{2} \mathrm{O}_{4}$ where $\mathrm{A}$ and $\mathrm{B}$ are divalent and trivalent cations, respectively. It occurs in nature as minerals and also synthesize in the laboratory with specific properties for special applications. Natural-occurring spinel is ruby $\mathrm{MgAl}_{2} \mathrm{O}_{4}$, a pink gemstone. The structure of spinel is a cubic crystal system, as shown in Fig. 15. The spinel structure was firstly reported by Bragg (1915). The unit cell of the spinel structure consists of the A in the tetrahedral site and B in the octahedral site. The spinel consists of a cubic closepacked array of oxide ions, in which one eighth of the tetrahedral sites and one half of the octahedral sites are occupied by cations. Tetrahedral sites' cations are surrounded by four oxygen atoms while octahedral site cations are surrounded by six oxygen atoms.

Due to its robustness in structure, it is a stable compound for oxidation reactions. The presence of cations of different metals occupy the position in tetrahedral as well as octahedral site that means the variable valance cations are present on the catalyst surface to facilitate reactions. Thus, the spinels have a good application in various fields of science and engineering due to its outstanding characteristics like good catalytic activity, excellent electrical, magnetic, and optical properties (Tatarchuk et al. 2016). On the basis of position of cations in the structure, the spinels are classified in three different categories: normal, inverse, and mixed spinels. The structure of all types of spinels with examples is given in Table 10 .

The brief discussion on the structure and application of different categories of spinels are given below:

\section{a Normal spinel}

In the normal spinel, the divalent cations occupy the A sites (in tetrahedral voids) and only trivalent cations occupy the $\mathrm{B}$

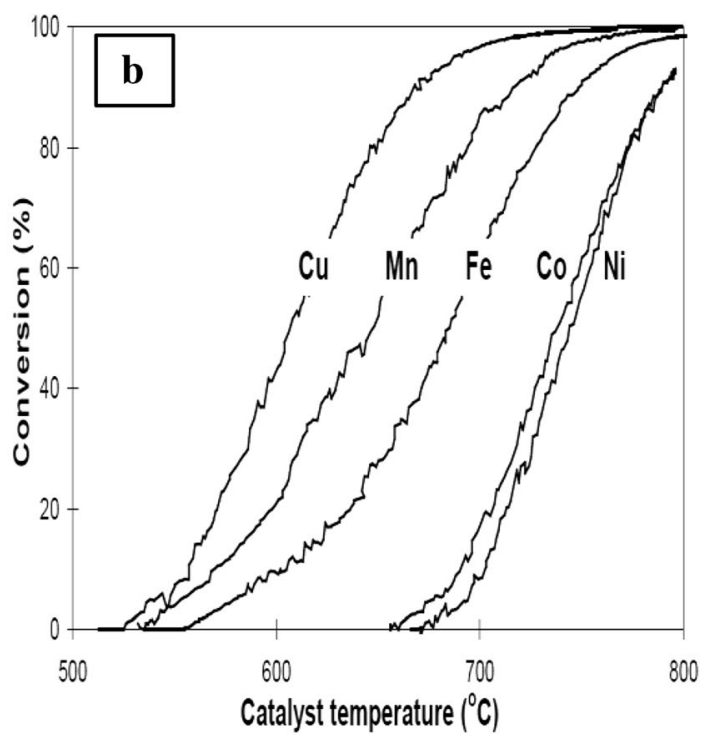

sites (in octahedral voids) and the distribution is represented by the formula $\left(\mathrm{A}^{2+}\right)_{t}\left[\mathrm{~B}_{2}{ }^{3+}\right]_{0} \mathrm{O}_{4}$ (see Table 10). An example of normal spinel is $\mathrm{Co}_{3} \mathrm{O}_{4}$ (Hastings and Corliss 1953). In the $\mathrm{Co}_{3} \mathrm{O}_{4}$ structure, $\mathrm{Co}^{2+}$ occupies 8 tetrahedral sites, $\mathrm{Co}^{3+}$ occupies 16 octahedral sites, and 32 sites are occupied by $\mathrm{O}^{2-}$ ions. The other representation of spinel is $\mathrm{CoO} \cdot \mathrm{Co}_{2} \mathrm{O}_{3}$. These can be used as magnetic nanoparticles in micro-batteries, nanowires, in electrode, as carbides, in catalysis, etc. The other application of spinel is as superconductors, as an electronic ceramics, and also good for oxidation reactions. The spinel is good catalyst for $\mathrm{CO}$ oxidation and sometimes used for $\mathrm{CH}_{4}$ oxidation. It can lower down the $\mathrm{CO}$ and $\mathrm{CH}_{4}$ reaction temperature. Among various catalysts, $\mathrm{CO}_{3} \mathrm{O}_{4}$ is a good catalyst and has a promising activity for oxidation of both gases (Cunningham et al. 1994; Dou et al. 2017; Garbowski et al. 1990; Meng et al. 1997; Shelef et al. 1968; Yu Yao 1974). The temperature for $\mathrm{CO}$ oxidation over $\mathrm{Co}_{3} \mathrm{O}_{4}$ was $\leq 54{ }^{\circ} \mathrm{C}$ (Grillo et al. 2004). The performance of the catalysts is highly dependent on morphology, support used, preparation methods, etc., for example, the total oxidation temperature of $\mathrm{CO}$ over nanorod $\mathrm{Co}_{3} \mathrm{O}_{4}$ was reduced to $-23{ }^{\circ} \mathrm{C}$ in comparison with nanosphere catalyst (Xie et al. 2009).

The activity of the catalysts over supported catalysts were also checked by several researchers because real applicationsupported catalysts would be highly stable than bulk catalyst (Jansson 2000; Zhang et al. 2017). The performance of the catalysts varies when the different supports were used. The total oxidation of $\mathrm{CO}$ over $\mathrm{Co}_{3} \mathrm{O}_{4} / \mathrm{Al}_{2} \mathrm{O}_{3}$ was reported at room temperature (Jansson 2000). When the support was $\mathrm{CeO}_{2}$, the temperature for total oxidation was high $\sim 80^{\circ} \mathrm{C}$ (Zhang et al. 2017). As discussed earlier, spinel $\left(\mathrm{Co}_{3} \mathrm{O}_{4}\right)$ has a good catalytic performance for $\mathrm{CH}_{4}$ as well and its performance also depends on parameters such as support, precipitants, promoters, etc. A numerous studies are available for $\mathrm{CH}_{4}$ 
Table 9 Literature review at a glance of $\mathrm{CO}$ and $\mathrm{CH}_{4}$ oxidation over mixed oxides

\begin{tabular}{|c|c|c|c|}
\hline Ref. & Catalyst/preparation technique & Experimental parameters & Remarks \\
\hline \multicolumn{4}{|l|}{ CO oxidation } \\
\hline Dongsheng et al. (2010) & $\begin{array}{l}\mathrm{CeO}_{2}-\mathrm{MO}_{x}(\mathrm{M}=\mathrm{Cu}, \mathrm{Mn}, \\
\mathrm{Fe}, \mathrm{Co} \text {, and } \mathrm{Ni}) \text {; citric acid } \\
\text { complexation-combustion }\end{array}$ & $\begin{array}{l}\text { Catalyst wt. } 100 \mathrm{mg} ; 1 \% \mathrm{CO} \text { and } 10 \% \\
\mathrm{O}_{2} \text { balanced by Ar; total flow rate, } \\
50 \mathrm{ml} \mathrm{min}\end{array}$ & $\begin{array}{c}\mathrm{Ce}_{0.9} \mathrm{Co}_{0.1} \mathrm{O}_{2-\delta} \text { without } \mathrm{H}_{2} \mathrm{O} \\
T_{50}=131^{\circ} \mathrm{C} ; \text { with } \mathrm{H}_{2} \mathrm{O}: \\
T_{50}=148{ }^{\circ} \mathrm{C}\end{array}$ \\
\hline Biabani-Ravandi and Rezaei (2012) & $\mathrm{Fe}-\mathrm{Co}(5 / 1)$ mixed oxide & $\begin{array}{l}\text { Catalyst wt. } 100 \mathrm{mg} ; 4 \% \mathrm{CO} \text { and } 20 \% \\
\mathrm{O}_{2} \text { balanced by } \mathrm{N}_{2} \text {; total flow rate, } \\
100 \mathrm{ml} \mathrm{min}^{-1}\end{array}$ & $\begin{array}{l}T_{100}=200^{\circ} \mathrm{C} \text {, activity } \\
\text { decreases with rise in WHSV }\end{array}$ \\
\hline Heo et al. (2014) & $\begin{array}{l}\text { Cerium zirconium mixed oxide } \\
\text { containing copper } \\
(\mathrm{Ce}-\mathrm{Zr}-\mathrm{Cu})\end{array}$ & $\begin{array}{l}\text { Catalyst wt.105.60 mg; } 0.05 \% \mathrm{CO} \\
0.026 \%, \mathrm{C}_{3} \mathrm{H}_{6}, 0.009 \% \mathrm{C}_{3} \mathrm{H}_{8} \\
0.0112 \% \mathrm{C}_{12} \mathrm{H}_{26}, 0.083 \% \mathrm{C}_{8} \mathrm{H}_{10} \\
0.02 \% \mathrm{NO}, 0.0008 \% \mathrm{O}_{2}, 0.0008 \% \\
\mathrm{H}_{2} \mathrm{O} \text { balanced with } \mathrm{N}_{2}\end{array}$ & $\mathrm{Ce}_{0.6} \mathrm{Zr}_{0.15} \mathrm{Cu}_{0.25} \mathrm{O}_{2}, T_{100}<150^{\circ} \mathrm{C}$ \\
\hline \multicolumn{4}{|l|}{$\mathrm{CH}_{4}$ oxidation } \\
\hline Li et al. (2009) & $\begin{array}{l}\mathrm{Co} / \mathrm{Mn} \text { mixed oxides } \\
\quad(\mathrm{Co}: \mathrm{Mn}=5: 1)\end{array}$ & $\begin{array}{l}\text { Catalyst wt.500 mg; } 1 \% \mathrm{CH}_{4} ; 10 \% \mathrm{O}_{2} \\
\text { balanced with } \mathrm{N}_{2} ; \text { total flow rate, } \\
150 \mathrm{ml} \mathrm{min}^{-1}\end{array}$ & $T_{90}<340{ }^{\circ} \mathrm{C}$ \\
\hline Dongsheng et al. (2010) & $\begin{array}{l}\mathrm{CeO}_{2}-\mathrm{MO}_{x}(\mathrm{M}=\mathrm{Cu}, \mathrm{Mn}, \mathrm{Fe}, \\
\quad \mathrm{Co} \text {, and } \mathrm{Ni})\end{array}$ & $\begin{array}{l}\text { Catalyst wt. } 100 \mathrm{mg} ; 1 \% \mathrm{CH}_{4} \text { and } 10 \% \\
\mathrm{O}_{2} \text { balanced by Ar; total flow rate, } \\
50 \mathrm{ml} \mathrm{min}\end{array}$ & $\begin{array}{l}\mathrm{Ce}_{0.9} \mathrm{Co}_{0.1} \mathrm{O}_{2-\delta} \text { without } \\
\mathrm{H}_{2} \mathrm{O}: T_{50}=510{ }^{\circ} \mathrm{C} ; \text { with } \\
\mathrm{H}_{2} \mathrm{O}, T_{50}=515^{\circ} \mathrm{C}\end{array}$ \\
\hline
\end{tabular}

oxidation over supported catalysts. McCarty et al. (1997) compared the activity of the various oxides for $\mathrm{CH}_{4}$ oxidation and reported the sequence in order of their performance: $\mathrm{Co}_{3} \mathrm{O}_{4}>\mathrm{CuO}>\mathrm{NiO}>\mathrm{Mn}_{2} \mathrm{O}_{3}>\mathrm{Cr}_{2} \mathrm{O}_{3}$. The authors checked the performance of the catalyst using various supports $\left(\mathrm{ZrO}_{2}\right.$, $\mathrm{MgO}, \mathrm{TiO}_{2}$, and $\mathrm{Al}_{2} \mathrm{O}_{3}$ ) for $\mathrm{CH}_{4}$ combustion. They found that $\mathrm{ZrO}_{2}$ and $\mathrm{Al}_{2} \mathrm{O}_{3}$ supports are themselves active with metal oxide whereas $\mathrm{MgO}$ and $\mathrm{TiO}_{2}$ are inactive supports for the reaction (Xiao et al. 2001). Recently, Tang et al. (2009) reported the total conversion temperature of $\mathrm{CH}_{4}$ over $\mathrm{Co}_{3} \mathrm{O}_{4}$ $\mathrm{SnO}_{2}$ is $500{ }^{\circ} \mathrm{C}$. It was good observation because the total oxidation of $\mathrm{CH}_{4}$ is not an easy task and it of course would require little bit high temperature. The reason behind the complete conversion is high mobility of oxygen species due to a strong interaction between cobalt and tin oxides (Tang et al.
2009). Thus, the main advantage of supported catalysts is that it can reduce the cost of bulk catalysts as well as participate to improve its performance.

Similarly, the authors studied the effect of precipitants on the performance of $\mathrm{CeO}_{2}$-supported $\mathrm{Co}_{3} \mathrm{O}_{4}$ catalyst (Wu et al. 2015). Wu et al. (2015) found that precipitating agents affected the textural (crystallite size and specific surface area) as well as catalytic properties of both. The addition of promoters affects the lights off characteristics of catalyst for $\mathrm{CH}_{4}$ combustion. Xu et al. (2014) studied the effect of Sm addition on the performance of $\mathrm{Co}_{3} \mathrm{O}_{4}$ for $\mathrm{CO}$ and $\mathrm{CH}_{4}$ oxidation. The authors found that the presence of $\mathrm{Sm}$ in the catalysts increases the conversion of $\mathrm{CH}_{4} 55 \%$ to $100 \%$ at temperature of more than $500{ }^{\circ} \mathrm{C}$ and decreases the temperature for $\mathrm{CO}$ oxidation from 190 to $125^{\circ} \mathrm{C}$. The reason behind the good

Fig. 15 Spinel structure $\left(\mathrm{AB}_{2} \mathrm{O}_{4}\right)$
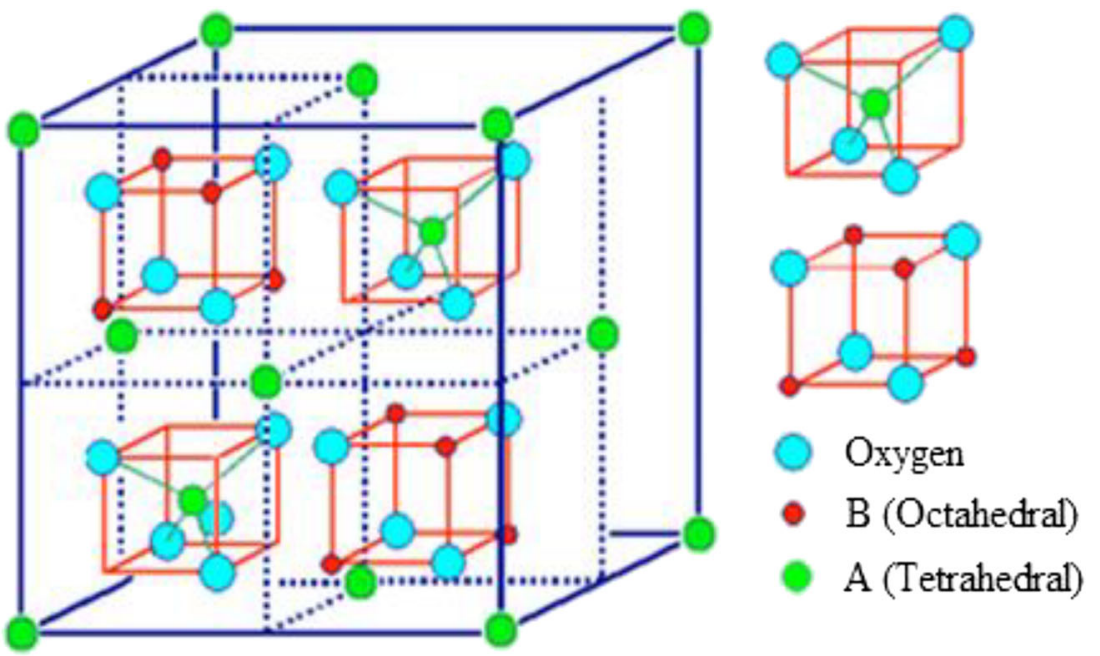
Table 10 Different types of spinels

\begin{tabular}{llll}
\hline Type & General formula & Example & Ref. \\
\hline Normal & $\left(\mathrm{A}^{2+}\right)_{\mathrm{t}}\left[\mathrm{B}_{2}{ }^{3+}\right]_{\mathrm{o}} \mathrm{O}_{4}$ & $\mathrm{Co}_{3} \mathrm{O}_{4}, \mathrm{ZnCo}_{2} \mathrm{O}_{4}$, etc. & Park et al. (2015) \\
Inverse & $\left(\mathrm{B}^{3+}\right)_{\mathrm{t}}\left[\mathrm{A}^{2+} \mathrm{B}^{3+}\right]_{\mathrm{o}} \mathrm{O}_{4}$ & $\mathrm{NiCo}_{2} \mathrm{O}_{4}, \mathrm{Fe}_{3} \mathrm{O}_{4}$, etc. & Park et al. (2015) \\
Mixed & $\left(\mathrm{A}^{2+}{ }_{x} \mathrm{~B}^{3+}{ }_{1-x}\right)_{\mathrm{t}}\left[\mathrm{A}^{2+}{ }_{1-x} \mathrm{~B}^{3+}{ }_{1+x}\right]_{\mathrm{o}} \mathrm{O}_{4}$ & $\mathrm{CuFe}_{2} \mathrm{O}_{4}, \mathrm{MgFe}_{2} \mathrm{O}_{4}$, etc. & Park et al. (2015) \\
\hline
\end{tabular}

“( )" represent tetrahedral site; "[ ]" represents octahedral sites performance of the catalysts is that Sm modified the spinel and formed amorphous $\mathrm{SmCoO}_{3}$ dispersed on the catalyst surface, which enhanced the concentration of $\mathrm{Co}^{3+}$ cation on the catalyst surface. The Sm could also form a more active oxygen species on the catalyst surface (Xu et al. 2014). Wang et al. (2020) recently synthesized a core-shell catalyst to enhance the performance of $\mathrm{Co}_{3} \mathrm{O}_{4}$ catalyst for $\mathrm{CH}_{4}$ oxidation. The hydrothermally prepared core-shell flower-spheroidal $\mathrm{Co}-$ Mn catalyst showed better activity along with a low risk of sintering of $\mathrm{Co}_{3} \mathrm{O}_{4}$ particles. The complete oxidation of $\mathrm{CH}_{4}$ over $\mathrm{Mn}$-incorporated $\mathrm{Co}_{3} \mathrm{O}_{4}$ occurred at temperature of $450{ }^{\circ} \mathrm{C}$ while $6 \%$ less conversion was obtained over $\mathrm{Co}_{3} \mathrm{O}_{4} /$ $\mathrm{SiO}_{2}$ at the same temperature. The $\mathrm{Mn}^{2+}$ ion replaced $\mathrm{Co}^{2+}$ in $\mathrm{Co}_{3} \mathrm{O}_{4}$ spinel that promotes the mobility and production of reactive oxygen species which improves performance.

In simultaneous $\mathrm{CO}-\mathrm{CH}_{4}$ oxidation, the mechanism will be different over the same catalyst. Both reactants affect the performance of each other. The activity for $\mathrm{CO}$ oxidation is likely to be related to the low $\Delta \mathrm{H}$ of vaporization of $\mathrm{O}_{2}$. Desorption of the lattice oxygen can be influenced by the $\mathrm{Co}-\mathrm{O}$ bond strength (Haneda et al. 2003). The simple mechanism for $\mathrm{CO}$ oxidation is that the $\mathrm{CO}$ reacts with the lattice or preadsorbed oxygen, which may further react to form carbonate species. A complete understanding of the sequence of elementary for $\mathrm{CO}$ oxidation is still confusing. In regard to catalytic oxidation of $\mathrm{CH}_{4}$, the lights off characteristics is related to the activity of the catalysts. The lights off characteristics of a catalyst is defined as $T_{10}, T_{50}$, and $T_{100}$ as the temperature corresponding to the 10,50 , and $100 \%$ conversion of reactant, respectively. The rate-controlling step for $\mathrm{CH}_{4}$ combustion is the $\mathrm{C}-\mathrm{H}$ bond breaking (Baldi et al. 1998). The summarized report of $\mathrm{CO}_{3} \mathrm{O}_{4}$ catalyst for $\mathrm{CO}$ and $\mathrm{CH}_{4}$ oxidation is mentioned in Table 11.

As we know, $\mathrm{CO}_{3} \mathrm{O}_{4}$ is a good catalyst for $\mathrm{CO}$ and $\mathrm{CH}_{4}$ oxidation. The main limitation of this catalyst is its toxicity and low thermal stability as compared with the other catalysts like perovskite. The other problem of this catalyst is that it showed a maximum possible conversion at a very high temperature. So, it cannot be considered a perfect catalyst for simultaneous oxidation of $\mathrm{CO}$ and $\mathrm{CH}_{4}$ gaseous mixture. Therefore, it is a mandate to identify low cost, eco-friendly, and stable transition metals for partial replacement of normal $\mathrm{Co}_{3} \mathrm{O}_{4}$ spinel which could make it complete eco-friendly and also improving its catalytic activity, selectivity, as well as stability.

\section{b Mixed spinel}

The mixed spinel is not much popular as inverse and normal spinels. The ionic distribution in the mixed spinel is intermediate between normal and inverse configuration. The distribution in this case is represented by the formula $\left(\mathrm{A}^{2+}{ }_{x}\right.$ $\left.\mathrm{B}^{3+}{ }_{1-x}\right)_{t}\left[\mathrm{~A}^{2+}{ }_{1-x} \mathrm{~B}^{3+}{ }_{1+x}\right]_{0} \mathrm{O}_{4}$. The example of mixed cation distribution is $\mathrm{NiFe}_{2} \mathrm{O}_{4}$ (Chinnasamy et al. 2001). Till now, no report is available over mixed spinel for the oxidation of $\mathrm{CO}$ and $\mathrm{CH}_{4}$.

\section{c Inverse spinel}

In inverse spinel, half of the trivalent cations occupy A sites and the other half of the trivalent cations and total divalent cations randomly occupy $\mathrm{B}$-sites $\left(\mathrm{B}^{3+}\right)_{t}\left[\mathrm{~A}^{2+} \mathrm{B}^{3+}\right]_{0} \mathrm{O}_{4}$. An example of inverse spinel is $\mathrm{NiCo}_{2} \mathrm{O}_{4}$, in which all the divalent cations of Co occupy only the $\mathrm{B}$ sites (Hastings and Corliss 1953). The cobaltites like $\mathrm{MCo}_{2} \mathrm{O}_{4}(\mathrm{M}=\mathrm{Ni}, \mathrm{Cu}, \mathrm{Mn}, \mathrm{Zn}, \mathrm{Mg}$, $\mathrm{Fe}$, etc.) are the examples of the inverse spinel catalysts. It is generally regarded as a mixed valance $\left(\mathrm{Co}^{3+} / \mathrm{Co}^{2+}\right.$ and $\mathrm{M}^{3+} /$ $\mathrm{M}^{2+}$ ) oxide that adopts spinel structure in which the $\mathrm{M}$ occupies the octahedral site and Co is distributed over both tetrahedral and octahedral sites.

Recently, inverse spinel have drawn significant attention for many technological applications ranging from catalysts and sensors to electrode material, electrochromic devices and supercapacitor due to their superior physicochemical properties. It was found that only inverse spinel such as $\mathrm{NiCo}_{2} \mathrm{O}_{4}$ has good catalytic activity for the oxidation of $\mathrm{CO}$ as well as $\mathrm{CH}_{4}$ also. However, few studies are reported in the literature for the oxidation of $\mathrm{CO}$ and $\mathrm{CH}_{4}$ over $\mathrm{NiCo}_{2} \mathrm{O}_{4}$ catalyst. So far, only three reports are available on $\mathrm{NiCo}_{2} \mathrm{O}_{4}$ for $\mathrm{CO}$ oxidation till now (Gou et al. 2013b; He et al. 2015; Zhu and Gao 2009b) and single paper on $\mathrm{CH}_{4}$ oxidation (Tao et al. 2015). Zhu and Gao (2009a) prepared a mesoporous cobaltites $\left(\mathrm{MCo}_{2} \mathrm{O}_{4}, \mathrm{M}=\mathrm{Cu}, \mathrm{Mn}\right.$, and $\left.\mathrm{Ni}\right)$ by a nanocasting pathway for $\mathrm{CO}$ oxidation, where SBA-15 is used as hard template. The authors found that $\mathrm{CuCo}_{2} \mathrm{O}_{4}$ and $\mathrm{MnCo}_{2} \mathrm{O}_{4}$ exhibited high activity and robust stability than $\mathrm{NiCo}_{2} \mathrm{O}_{4}$. The temperature for total $\mathrm{CO}$ oxidation over $\mathrm{CuCo}_{2} \mathrm{O}_{4}$ and $\mathrm{MnCo}_{2} \mathrm{O}_{4}$ were (69) and $73{ }^{\circ} \mathrm{C}$, respectively. In contrast with the other cobaltites, the $\mathrm{NiCo}_{2} \mathrm{O}_{4}$ showed the poor activity and continuous deactivation during life/stability test. Further, a 
Table 11 Light off characteristics for oxidation of $\mathrm{CO}$ and $\mathrm{CH}_{4}$ over $\mathrm{Co}_{3} \mathrm{O}_{4}$ catalyst

\begin{tabular}{|c|c|c|c|}
\hline Ref. & Catalyst/preparation technique & Experimental parameters & Remarks \\
\hline \multicolumn{4}{|l|}{ CO oxidation } \\
\hline Wei et al. (2010) & $\mathrm{Co}_{3} \mathrm{O}_{4}$ & $\begin{array}{l}200 \mathrm{mg} \text { catalyst wt., } 1 \% \mathrm{CO} \text { balanced } \\
\text { with } \mathrm{O}_{2} \text { and } \mathrm{He} \text {, total flow rate: } \\
50 \mathrm{ml} / \mathrm{min} .\end{array}$ & $T_{100}=-77^{\circ} \mathrm{C}$ \\
\hline Xu et al. (2014) & $\mathrm{Co}_{1-x} \mathrm{Sm}_{x} \mathrm{O}_{3}(x: 0.10-0.98)$ & $\begin{array}{l}100 \mathrm{mg} \text { catalyst wt.; } 1 \% \mathrm{CO} \text {, balanced } \\
\text { with } \mathrm{O}_{2} \text { and } \mathrm{N}_{2} \text {; total flow rate, } \\
30 \mathrm{ml} \mathrm{min}^{-1}\end{array}$ & $\begin{array}{l}T_{100}=120{ }^{\circ} \mathrm{C} \text { over best } \\
\quad \text { composition } \mathrm{Co}_{0.90} \mathrm{Sm}_{0.10}\end{array}$ \\
\hline \multicolumn{4}{|l|}{$\mathrm{CH}_{4}$ oxidation } \\
\hline Tang et al. (2009) & $\mathrm{Co}_{3} \mathrm{O}_{4}-\mathrm{SnO}_{2}$ & $\begin{array}{l}500 \mathrm{mg} \text { catalyst wt.; } 1.0 . \% \text { of } \mathrm{CH}_{4} \\
10.0 \% \mathrm{O}_{2} \text {, and } \mathrm{N}_{2} \text { balance; total } \\
\text { flow rate, } 150 \mathrm{ml} \mathrm{min}^{-1} ; \\
\text { GHSV }=18,000 \mathrm{~h}^{-1}\end{array}$ & $\begin{array}{l}\text { Optimum molar ration } \\
\mathrm{Co} /(\mathrm{Co}+\mathrm{Sn})=0.75 \\
\text { and } T_{100}=500^{\circ} \mathrm{C}\end{array}$ \\
\hline Xu et al. (2014) & $\mathrm{Co}_{1-x} \mathrm{Sm}_{x} \mathrm{O}_{3}(x: 0.10-0.98)$ & $\begin{array}{l}100 \mathrm{mg} \text { catalyst wt.; } 1 \% \mathrm{CO} \text {, balanced } \\
\text { with } \mathrm{O}_{2} \text { and } \mathrm{N}_{2} \text {; total flow rate, } \\
30 \mathrm{ml} \mathrm{min}^{-1}\end{array}$ & $\begin{array}{l}T_{100}=450{ }^{\circ} \mathrm{C} \text { for best } \\
\quad \text { composition } \mathrm{Co}_{0.95} \mathrm{Sm}_{0.05}\end{array}$ \\
\hline Wu et al. (2015) & $\mathrm{Co}_{3} \mathrm{O}_{4}-\mathrm{CeO}_{2}$ & $\begin{array}{l}50 \mathrm{mg} \text { catalyst wt.; } 0.3 \% \mathrm{CH}_{4} ; 0.6 \% \\
\mathrm{O}_{2} \text { in } \mathrm{He}(\lambda=1) ; \text { total flow rate, } \\
50 \mathrm{ml} \mathrm{min}\end{array}$ & $\begin{array}{l}T_{90}>487^{\circ} \mathrm{C} \text {, urea as } \\
\text { best precipitant }\end{array}$ \\
\hline Dou et al. (2017) & $\mathrm{Co}_{3} \mathrm{O}_{4} / \mathrm{CeO}_{2}$ & $\begin{array}{l}100 \mathrm{mg} \text { catalyst wt.; } 10 \% \mathrm{CH}_{4} \\
\text { balanced by } \mathrm{Ar} \text { and pure } \mathrm{O}_{2} \text {; total } \\
\text { flow rate, } 30 \mathrm{ml} \mathrm{min}^{-1}\end{array}$ & $T_{100} \leq 600^{\circ} \mathrm{C}$ \\
\hline Wang et al. (2020) & $\mathrm{Mn}_{1} / \mathrm{Co} / \mathrm{SiO}_{2}$ & $\begin{array}{l}100 \mathrm{mg} \text { catalyst wt.; } 0.1 \mathrm{vol} \% \mathrm{CH}_{4} \\
\text { in air; GHSV }=6000 \mathrm{~mL} \mathrm{hg}^{-1}\end{array}$ & $T_{100}=450^{\circ} \mathrm{C}$ \\
\hline
\end{tabular}

Table 12 Literature for oxidation of $\mathrm{CO}, \mathrm{CH}_{4}$, and their mixture over $\mathrm{NiCo}_{2} \mathrm{O}_{4}$ catalyst

\begin{tabular}{|c|c|c|c|}
\hline Ref. & Catalyst/preparation technique & Experimental parameters & Remarks \\
\hline \multicolumn{4}{|l|}{ CO oxidation } \\
\hline Zhu and Gao (2009a) & $\begin{array}{c}\mathrm{MCo}_{2} \mathrm{O}_{4}(\mathrm{M}=\mathrm{Cu}, \mathrm{Mn} \text {, and } \mathrm{Ni}) \\
\text { Nanocasting pathway using } \\
\text { SBA-15 as a hard template }\end{array}$ & $\begin{array}{l}50 \text { mg catalyst wt.; } 1.0 \% \mathrm{CO} \\
\text { in air; total flow rate, } 100 \mathrm{ml} \mathrm{min}{ }^{-1}\end{array}$ & $\begin{array}{l}T_{50}=69{ }^{\circ} \mathrm{C} \text { for } \mathrm{CuCo}_{2} \mathrm{O}_{4} ; \\
T_{50}=73{ }^{\circ} \mathrm{C} \text { for } \mathrm{MnCo}_{2} \mathrm{O}_{4} ; \\
T_{50}=89{ }^{\circ} \mathrm{C} \text { for } \mathrm{NiCo}_{2} \mathrm{O}_{4}\end{array}$ \\
\hline Gou et al. (2013a) & $\mathrm{Ni}-\mathrm{Co}$ nanosheets; co-ppt & $\begin{array}{l}200 \mathrm{mg} \text { catalyst wt., } 2 \% \mathrm{CO}, \\
20 \% \mathrm{O}_{2}, 78 \% \text { Ar; total flow rate, } \\
50 \mathrm{ml} \mathrm{min}^{-1} \text {; total flow rate, } \\
200 \mathrm{ml} \mathrm{min}^{-1}\end{array}$ & $T_{100}=-77^{\circ} \mathrm{C}$ \\
\hline Prasad and Singh (2013) & $\mathrm{NiCo}_{2} \mathrm{O}_{4} ;$ co-ppt & 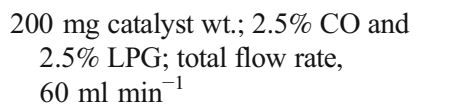 & $T_{100}=105^{\circ} \mathrm{C}$ \\
\hline \multicolumn{4}{|l|}{$\mathrm{CH}_{4}$ oxidation } \\
\hline Tao et al. (2015) & $\mathrm{NiCo}_{2} \mathrm{O}_{4}$; co-ppt. & $\begin{array}{l}500 \mathrm{mg} \text { catalyst wt.; } 10 \% \mathrm{CH}_{4} \text { in } \\
\text { Ar; total flow rate, } 100 \mathrm{~m} \mathrm{~min}^{-1}\end{array}$ & $T_{90}=340{ }^{\circ} \mathrm{C}$ \\
\hline \multicolumn{4}{|l|}{$\mathrm{CO}-\mathrm{CH}_{4}$ mixture } \\
\hline Trivedi and Prasad (2017b) & $\begin{array}{l}\mathrm{NiCo}_{2} \mathrm{O}_{4} ; \text { co-ppt.; sol-gel; reactive } \\
\text { grinding; reactive calcination }\end{array}$ & $\begin{array}{l}500 \mathrm{mg} \text { catalyst wt.; } 1.5 \% \mathrm{CO} \text { and } \\
\mathrm{CH}_{4} \text { each; total flow rate, } \\
100 \mathrm{ml} \mathrm{min}\end{array}$ & $\begin{array}{l}\text { The best method of preparation } \\
\text { is co-ppt.; Acc. to activity, } \\
\text { order of preparation method: } \\
\text { Co-ppt. > Reactive } \\
\text { grinding > Sol-gel }\end{array}$ \\
\hline Trivedi and Prasad (2017a) & $\begin{array}{l}\mathrm{NiCo}_{2} \mathrm{O}_{4} \text {; co-ppt. method; } \\
\text { precipitants- }-\mathrm{KOH} \mathrm{Na} \mathrm{CO}_{3} \\
\text { and urea; reactive calcination }\end{array}$ & $\begin{array}{l}500 \mathrm{mg} \text { catalyst wt.; } 1.5 \% \mathrm{CO} \text { and } \\
\mathrm{CH}_{4} \text { each, total flow rate: } \\
100 \mathrm{ml} / \mathrm{min} .\end{array}$ & $\begin{array}{l}\text { Best precipitating agent- } \mathrm{Na}_{2} \mathrm{CO}_{3} ; \\
\text { Acc. to activity, order of } \\
\mathrm{Na}_{2} \mathrm{CO}_{3}>\text { urea }>\mathrm{KOH}\end{array}$ \\
\hline Trivedi and Prasad (2018) & $\begin{array}{l}2 \% \mathrm{~K}, 1 \% \text { Pd-NiCo } \mathrm{NiO}_{2} ; \text { co-ppt. } \\
\text { Followed by spraying; } \\
\text { Reactive calcination }\end{array}$ & $\begin{array}{l}500 \mathrm{mg} \text { catalyst wt.; } 1.5 \% \mathrm{CO} \text { and } \\
\mathrm{CH}_{4} \text { each; total flow rate, } \\
100 \mathrm{ml} \mathrm{min}\end{array}$ & $\begin{array}{l}T_{100}=320{ }^{\circ} \mathrm{C} \text {; activity order, } \\
2 \% \mathrm{~K} 0.1 \% \text { Pd-NiCo } \mathrm{O}_{4}>0.1 \% \\
\mathrm{PdNiCo}_{2} \mathrm{O}_{4}>2 \% \mathrm{~K} \\
\mathrm{NiCo}_{2} \mathrm{O}_{4}>\mathrm{NiCo}_{2} \mathrm{O}_{4}\end{array}$ \\
\hline Trivedi and Prasad (2018) & $\begin{array}{l}\mathrm{NiCo}_{2} \mathrm{O}_{4} ; \text { co-ppt. method; } \\
\text { reactive calcination }\end{array}$ & $\begin{array}{l}500 \mathrm{mg} \text { catalyst wt.; } 1.5 \% \mathrm{CO} \text { and } \\
\mathrm{CH}_{4} \text {; total flow rate, } 100 \mathrm{ml} \mathrm{min}\end{array}$ & $\begin{array}{l}\text { For } \mathrm{CO}, T_{100}=130{ }^{\circ} \mathrm{C} \text {; for } \\
\qquad \mathrm{CH}_{4}, T_{100}=350{ }^{\circ} \mathrm{C}\end{array}$ \\
\hline
\end{tabular}


series of Ni-Co oxides was prepared by Gou et al. (2013b) for $\mathrm{CO}$ oxidation. A stable lamellar structure of $\mathrm{NiCo}_{2} \mathrm{O}_{4}$ was formed when the Co percentage was between 40 and $60 \%$. The Ni-Co binary oxides are categorized into three categories such as $\mathrm{NiO}, \mathrm{Co}_{3} \mathrm{O}_{4}$, and $\mathrm{NiCo}_{2} \mathrm{O}_{4}$. The $\mathrm{NiO}$ showed the better catalytic activity in comparison with $\mathrm{Co}_{3} \mathrm{O}_{4}$ and $\mathrm{NiCo}_{2} \mathrm{O}_{4}$. The lights off temperature for $\mathrm{CO}$ oxidation was $75^{\circ} \mathrm{C}$ over $\mathrm{NiO}$ catalyst (Gou et al. 2013b). He et al. (2015) reported the complete oxidation of $\mathrm{CO}$ at low temperature of $115{ }^{\circ} \mathrm{C}$ over a hexangular ring-core $\mathrm{NiCo}_{2} \mathrm{O}_{4}$ porous nanosheets/NiO nanoparticle composite.

The temperature for total oxidation $\mathrm{CO}$ was relatively higher over $\mathrm{NiCo}_{2} \mathrm{O}_{4}$ in comparison with individual constituents of this catalyst. However, the $\mathrm{NiCo}_{2} \mathrm{O}_{4}$ possesses the best performance for $\mathrm{CH}_{4}$ oxidation and $90 \%$ conversion of $\mathrm{CH}_{4}$ oxidation was reported at a low temperature of $350{ }^{\circ} \mathrm{C}$ (Tao et al. 2015). Thus, it is a topic of attention in recent years to explore $\mathrm{NiCo}_{2} \mathrm{O}_{4}$ catalyst for $\mathrm{CO}$ and $\mathrm{CH}_{4}$ oxidation. Literature review at a glimpse for separate and simultaneous oxidation of $\mathrm{CO}$ and $\mathrm{CH}_{4}$ over $\mathrm{NiCo}_{2} \mathrm{O}_{4}$ is mentioned in Table 12.

Little work is available in literature for simultaneous oxidation of $\mathrm{CO}-\mathrm{CH}_{4}$ mixture over $\mathrm{NiCo}_{2} \mathrm{O}_{4}$. Trivedi and Prasad $(2016,2017 \mathrm{a}, \mathrm{b}, 2018)$ studied the oxidation of $\mathrm{CO}-\mathrm{CH}_{4}$ mixture over $\mathrm{NiCo}_{2} \mathrm{O}_{4}$ and found a very low temperature of $350{ }^{\circ} \mathrm{C}$ for complete oxidation reaction. The authors found that it is very stable catalyst and maintained its activity for a long period of $50 \mathrm{~h}$ at complete combustion temperature $\left(350{ }^{\circ} \mathrm{C}\right)$ of $\mathrm{CO}-\mathrm{CH}_{4}$ mixture. They also explained the synergistic effect of reactants in the mixture, i.e., $\mathrm{CO}$ facilitates oxidation of $\mathrm{CH}_{4}$ by lowering its complete combustion temperature. Further, the authors appreciated the addition of dopants in the inverse spinel and found the lowest temperature of $320{ }^{\circ} \mathrm{C}$ for oxidation of the $\mathrm{CO}-\mathrm{CH}_{4}$ mixture over $\mathrm{K}-\mathrm{Pd}$ doped $\mathrm{NiCo}_{2} \mathrm{O}_{4}$.

\section{Conclusion}

The best approach to curb the threat of vehicular pollution and the choice of the appropriate catalyst for the converters is a vital step in terms of activity, selectivity, durability, availability, and cost. The noble metals are completely replaceable with transition metal to abate pollutants nowadays. In the same line, the cobalt-based catalysts exhibit good catalytic performance for $\mathrm{CO}$ and $\mathrm{CH}_{4}$ oxidation under lean conditions. Moreover, Co-based catalyst can effectively remove three major pollutants $\left(\mathrm{CO}, \mathrm{HCs}\right.$, and $\left.\mathrm{NO}_{x}\right)$ from the exhaust in the temperature region considerably lower than flame or explosion temperatures $\left(150-450{ }^{\circ} \mathrm{C}\right)$. However, the presence of poisoning compounds in exhaust stream can reduce the performance or affect activity of the catalyst. The performance of the catalyst is highly dependent upon some important parameters like supports, preparation methods, precipitants, etc. Among the different types of spinel, $\mathrm{NiCo}_{2} \mathrm{O}_{4}$ is well studied and a good one for $\mathrm{CO}-\mathrm{CH}_{4}$ oxidation. Still, research is required in order to develop the catalysts for oxidation of $\mathrm{CO}-\mathrm{CH}_{4}$ mixture using newer recently investigated routes. The present paper opens a new horizons or opportunity for the "cobalt based catalyst" as competitive catalysts in methane combustion reaction.

Acknowledgements A. K. is thankful to Dean of Scientific Research, King Khalid University for financial support by grant number RGP 2/36/40.

\section{References}

Alifanti M, Florea M, Pârvulescu VI (2007) Ceria-based oxides as supports for $\mathrm{LaCoO}_{3}$ perovskite; catalysts for total oxidation of VOC. Applied Catalysis B: Environmental 70:400-405. https://doi.org/10. 1016/j.apcatb.2005.10.037

An N, Yuan X, Pan B, Li Q, Li S, Zhang W (2014) Design of a highly active $\mathrm{Pt} / \mathrm{Al}_{2} \mathrm{O}_{3}$ catalyst for low-temperature $\mathrm{CO}$ oxidation. RSC Advances 4:38250-38257

Andrews J, Shabani B (2012) Re-envisioning the role of hydrogen in a sustainable energy economy. International Journal of Hydrogen Energy 37:1184-1203. https://doi.org/10.1016/j.ijhydene.2011.09. 137

ARAI (2011) Regulation IE. ARAI, Pune

Arandiyan H (2015) Methane combustion over lanthanum-based perovskite mixed oxides. Springer

Bajracharya SR, Mool PK, Shrestha BR (2006) The impact of global warming on the glaciers of the Himalaya. In: Proceedings of the International Symposium on Geodisasters, Infrastructure Management and Protection of World Heritage Sites. pp 231-242

Baldi M, Escribano VS, Amores JMG, Milella F (1998) Characterization of manganese and iron oxides as combustion catalysts for propane and propene. Applied Catalysis B: Environmental 17:L175-L182

Bera P, Hegde M (2010) Recent advances in auto exhaust catalysis. Journal of the Indian Institute of Science 90:299-325

Bhandari K, Bansal A, Shukla A, Khare M (2005) Performance and emissions of natural gas fueled internal combustion engine: a review. Journal of Scientific and Industrial Research

Bhandarkar S, Nijagunappa R (2016) Comparative exhaust emission study of North East Karnataka road transport corporation buses by the use of alternative fuel-CNG. Journal of Aeronautical and Automotive Engineering

Biabani-Ravandi A, Rezaei M (2012) Low temperature CO oxidation over $\mathrm{Fe}-\mathrm{Co}$ mixed oxide nanocatalysts. Chemical Engineering Journal 184:141-146

Bragg WH (1915) XXX. The structure of the spinel group of crystals The London, Edinburgh, and Dublin. Philosophical Magazine and Journal of Science 30:305-315. https://doi.org/10.1080/ 14786440808635400

Brunetti M, Maugeri M, Nanni T (2001) Changes in total precipitation, rainy days and extreme events in northeastern Italy. International Journal of Climatology 21:861-871

Burch R, Urbano F, Loader P (1995) Methane combustion over palladium catalysts: the effect of carbon dioxide and water on activity. Applied Catalysis A: General 123:173-184

Cavani F, Trifirò F, Vaccari A (1991) Hydrotalcite-type anionic clays: preparation, properties and applications. Catal Today 11:173-301 
Chen C-Q, Li W, Cao C-Y, Song W-G (2010) Enhanced catalytic activity of perovskite oxide nanofibers for combustion of methane in coal mine ventilation air. Journal of Materials Chemistry 20:6968-6974

Cheng J, Yu J, Wang X, Li L, Li J, Hao Z (2008) Novel CH4 combustion catalysts derived from $\mathrm{Cu}-\mathrm{Co} / \mathrm{X}-\mathrm{Al}(\mathrm{X}=\mathrm{Fe}, \mathrm{Mn}, \mathrm{La}, \mathrm{Ce})$ hydrotalcite-like compounds. Energy \& Fuels 22:2131-2137

Chinnasamy $\mathrm{C}$ et al (2001) Mixed spinel structure in nanocrystalline NiFe2O4. Physical Review B 63:184108

Cho HM, He B-Q (2007) Spark ignition natural gas engines - a review. Energy Conversion and Management 48:608-618

Cho HM, He B-Q (2008) Combustion and emission characteristics of a lean burn natural gas engine. International Journal of Automotive Technology 9:415-422. https://doi.org/10.1007/s12239-008-00505

Choudhary VR, Patil VP, Jana P, Uphade BS (2008) Nano-gold supported on Fe2O3: a highly active catalyst for low temperature oxidative destruction of methane green house gas from exhaust/waste gases. Applied Catalysis a: General 350:186-190. https://doi.org/10.1016/ j.apcata.2008.08.008

Christensen M, Johansson B (1998) Influence of mixture quality on homogeneous charge compression ignition. SAE Technical Paper

Ciambelli P, Cimino S, De Rossi S, Lisi L, Minelli G, Porta P, Russo G (2001) $\mathrm{AFeO} 3(\mathrm{~A}=\mathrm{La}, \mathrm{Nd}, \mathrm{Sm})$ and $\mathrm{LaFe}_{1-\mathrm{x}} \mathrm{Mg}_{\mathrm{x}} \mathrm{O}_{3}$ perovskites as methane combustion and $\mathrm{CO}$ oxidation catalysts: structural, redox and catalytic properties. Applied Catalysis B: Environmental 29: 239-250. https://doi.org/10.1016/S0926-3373(00)00215-0

Cohn JG (1965) Process for selectively removing carbon monoxide from hydrogen-containing gases. Google Patents

Colussi S, Trovarelli A, Cristiani C, Lietti L, Groppi G (2012) The influence of ceria and other rare earth promoters on palladium-based methane combustion catalysts. Catalysis Today 180:124-130

Corrêa SM, Arbilla G (2005) Formaldehyde and acetaldehyde associated with the use of natural gas as a fuel for light vehicles. Atmospheric Environment 39:4513-4518. https://doi.org/10.1016/j.atmosenv. 2005.03.042

Cunningham D, Kobayashi T, Kamijo N, Haruta M (1994) Influence of dry operating conditions: observation of oscillations and low temperature $\mathrm{CO}$ oxidation over $\mathrm{Co}_{3} \mathrm{O}_{4}$ and $\mathrm{Au} / \mathrm{Co}_{3} \mathrm{O}_{4}$ catalysts. Catal Lett 25:257-264

Dongsheng Q, Guanzhong L, Yun G, Yanqin W, Yanglong G (2010) Effect of water vapor on the $\mathrm{CO}$ and $\mathrm{CH}_{4}$ catalytic oxidation over $\mathrm{CeO}_{2}-\mathrm{MO}_{\mathrm{x}}(\mathrm{M}=\mathrm{Cu}, \mathrm{Mn}, \mathrm{Fe}, \mathrm{Co}$, and $\mathrm{Ni})$ mixed oxide. Journal of Rare Earths 28:742-746

Dou J et al (2017) Complete oxidation of methane on $\mathrm{Co} 3 \mathrm{O} 4 / \mathrm{CeO} 2$ nanocomposite: a synergistic effect. Catalysis Today

EPA (2014) Climate change indicators in the United States. https://www. epa.gov/sites/production/files/2016-07/documents/ climateindicators-full-2014.pdf

Faramawy S, Zaki T, Sakr AAE (2016) Natural gas origin, composition, and processing: a review. Journal of Natural Gas Science and Engineering 34:34-54. https://doi.org/10.1016/j.jngse.2016.06.030

Ferrandon M (2001) Mixed metal oxide-Noble metal catalyst for total oxidation of volatile organic matter and carbon monoxide. $\mathrm{Ph}$. D. thesis, Dept. of Chemical Engineering and Technology, Royal Institute of Technology, Stolkholm

Forni L, Rossetti I (2002) Catalytic combustion of hydrocarbons over perovskites. Applied Catalysis B: Environmental 38:29-37. https:// doi.org/10.1016/S0926-3373(02)00024-3

Fortunato G, Oswald H, Reller A (2001) Spinel-type oxide catalysts for low temperature $\mathrm{CO}$ oxidation generated by use of an ultrasonic aerosol pyrolysis process. Journal of Materials Chemistry 11:905911

Fujitani T, Nakamura I, Haruta M (2014) Role of win CO oxidation on gold catalysts. Catalysts Letters 144:1475-1486. https://doi.org/10. 1007/s10562-014-1325-2
Garbowski E, Guenin M, Marion M-C, Primet M (1990) Catalytic properties and surface states of cobalt-containing oxidation catalysts. Applied catalysis 64:209-224

Gelin P, Urfels L, Primet M, Tena E (2003) Complete oxidation of methane at low temperature over Pt and Pd catalysts for the abatement of lean-burn natural gas fuelled vehicles emissions: influence of water and sulphur containing compounds. Catalysis Today 83:45-57

Genty E et al (2015) Co-Al mixed oxides prepared via LDH route using microwaves or ultrasound: application for catalytic toluene total oxidation. Catalysts 5:851-867

Ghaffari A, Shamekhi AH, Saki A, Kamrani E (2008) Adaptive fuzzy control for air-fuel ratio of automobile spark ignition engine. World Academy of Science Eng Technol 48:284-292

Gou Y, Liang X, Chen B (2013a) Porous Ni-Co bimetal oxides nanosheets and catalytic properties for CO oxidation. Journal of Alloys and Compounds 574:181-187. https://doi.org/10.1016/j.jallcom. 2013.04.053

Gou Y, Liang X, Chen B (2013b) Porous Ni-Co bimetal oxides nanosheets and catalytic properties for CO oxidation. Journal of Alloys and Compounds 574:181-187

Grillo F, Natile MM, Glisenti A (2004) Low temperature oxidation of carbon monoxide: the influence of water and oxygen on the reactivity of a $\mathrm{Co} 3 \mathrm{O} 4$ powder surface. Applied Catalysis B: Environmental 48:267-274

Grisel R, Nieuwenhuys B (2001) A comparative study of the oxidation of $\mathrm{CO}$ and $\mathrm{CH} 4$ over $\mathrm{Au} / \mathrm{MOx} / \mathrm{Al} 2 \mathrm{O} 3$ catalysts. Catal Today $64: 69-81$

Guo X, Li J, Zhou R (2016) Catalytic performance of manganese doped $\mathrm{CuO}-\mathrm{CeO} 2$ catalysts for selective oxidation of $\mathrm{CO}$ in hydrogen-rich gas. Fuel 163:56-64

Haneda M, Kintaichi Y, Bion N, Hamada H (2003) Alkali metal-doped cobalt oxide catalysts for $\mathrm{NO}$ decomposition. Applied Catalysis B: Environmental 46:473-482

Haq M, Rahman M, Bhutto Z Performance studies of a biogas fueled diesel engine operating in a dual fuel mode. In: Proc. of Int. Conf on Power Engineering: ICOPE, 2003. pp. 3-57

Haruta M, Yamada N, Kobayashi T, Iijima S (1989) Gold catalysts prepared by coprecipitation for low-temperature oxidation of hydrogen and of carbon monoxide. Journal of Catalysis 115:301-309. https:// doi.org/10.1016/0021-9517(89)90034-1

Hastings JM, Corliss LM (1953) Neutron diffraction studies of zinc ferrite and nickel ferrite. Reviews of Modern Physics 25:114-119

He Y, Xu L, Zhai Y, Li A, Chen X (2015) A hexangular ring-core $\mathrm{NiCo}_{2} \mathrm{O}_{4}$ porous nanosheet/NiO nanoparticle composite as an advanced anode material for LIBs and catalyst for CO oxidation applications. Chemical Communications 51:14768-14771

Heck RM, Farrauto RJ (2001) Automobile exhaust catalysts. Applied Catalysis A: General 221:443-457

Heo I, Wiebenga MH, Gaudet JR, Nam I-S, Li W, Kim CH (2014) Ultra low temperature $\mathrm{CO}$ and $\mathrm{HC}$ oxidation over $\mathrm{Cu}$-based mixed oxides for future automotive applications. Applied Catalysis B: Environmental 160:365-373

Heynderickx MP, Thybaut JW, Poelman H, Poelman D, Marin GB (2010) Kinetic modeling of the total oxidation of propane over $\mathrm{CuO}-\mathrm{CeO} 2 / \gamma-\mathrm{A} 12 \mathrm{O} 3$. Applied Catalysis B: Environmental 95:2638. https://doi.org/10.1016/j.apcatb.2009.11.018

Heywood JB (1988) Internal combustion engine fundamentals

Hossain R (2014) Training and development program for increasing employees performance in Navana. CNG Limited

Hussain M, Deorsola FA, Russo N, Fino D, Pirone R (2015) Abatement of $\mathrm{CH} 4$ emitted by $\mathrm{CNG}$ vehicles using Pd-SBA-15 and Pd-KIT-6 catalysts. Fuel 149:2-7

Iablokov V, Kruse N (2011) Manganese and cobalt oxides as highly active catalysts for $\mathrm{CO}$ oxidation. Université Libre de Bruxelles, Belgium, Ph. D. thesis

Ivanova S, Pitchon V, Zimmermann Y, Petit C (2006) Preparation of alumina supported gold catalysts: influence of washing procedures, 
mechanism of particles size growth. Applied Catalysis A: General 298:57-64. https://doi.org/10.1016/j.apcata.2005.09.020

Jansson $\mathrm{J}$ (2000) Low-temperature $\mathrm{CO}$ oxidation over $\mathrm{Co}_{3} \mathrm{O}_{4} / \mathrm{Al}_{2} \mathrm{O}_{3}$. Journal of Catalysis 194:55-60

Jiang Z, Yu J, Cheng J, Xiao T, Jones MO, Hao Z, Edwards PP (2010) Catalytic combustion of methane over mixed oxides derived from $\mathrm{Co}-\mathrm{Mg} / \mathrm{Al}$ ternary hydrotalcites. Fuel Processing Technology 91: 97-102. https://doi.org/10.1016/j.fuproc.2009.08.023

Kalam M et al (2009) Development and test of a new catalytic converter for natural gas fuelled engine. Sadhana 34:467-481

Kaltenborn BP, Nellemann C, Vistnes II (2010) High mountain glaciers and climate change: challenges to human livelihoods and adaptation. UNEP, GRID-Arendal

Kamel M, Lyford-Pike E, Frailey M, Bolin M, Clark N, Nine R, Wayne S (2002) An emission and performance comparison of the natural gas Cummins Westport Inc. C-Gas Plus versus diesel in heavy-duty trucks. SAE Technical Paper,

Khan MI, Yasmin T, Shakoor A (2015) Technical overview of compressed natural gas $(\mathrm{CNG})$ as a transportation fuel. Renewable and Sustainable Energy Reviews 51:785-797

Kowalewicz A (1984) Combustion systems of high-speed piston IC engines. Elsevier

Kowalewicz A, Wojtyniak M (2005) Alternative fuels and their application to combustion engines. Proceedings of the Institution of Mechanical Engineers Part D: Journal of Automobile Engineering 219:103-125

Kucharczyk B (2015) Catalytic oxidation of carbon monoxide on Pdcontaining LaMnO3 perovskites. Catalysis Letters 145:12371245. https://doi.org/10.1007/s10562-015-1518-3

Kumar M, Rattan G, Prasad R (2015) Catalytic abatement of methane emission from $\mathrm{CNG}$ vehicles: an overview. Canadian Chemical Transactions 3:381-409

Labhsetwar N, Biniwale RB, Kumar R, Rayalu S, Devotta S (2006) Application of supported perovskite-type catalysts for vehicular emission control. Catalysis Surveys from Asia 10:55-64. https:// doi.org/10.1007/s10563-006-9005-x

Lampert JK, Kazi MS, Farrauto RJ (1997) Palladium catalyst performance for methane emissions abatement from lean burn natural gas vehicles. Applied Catalysis B: Environmental 14:211-223

Li J, Liang X, Xu S, Hao J (2009) Catalytic performance of manganese cobalt oxides on methane combustion at low temperature. Applied Catalysis B: Environmental 90:307-312

Li Z, Hoflund GB (2003) A review on complete oxidation of methane at low temperatures. Journal of Natural Gas Chemistry 12:153-160

Liotta LF, Di Carlo G, Longo A, Pantaleo G, Venezia AM (2008) Support effect on the catalytic performance of $\mathrm{Au} / \mathrm{Co} 3 \mathrm{O} 4-\mathrm{CeO} 2$ catalysts for $\mathrm{CO}$ and $\mathrm{CH} 4$ oxidation. Catalysis Today 139:174 179. https://doi.org/10.1016/j.cattod.2008.04.025

Liotta LF, Wu H, Pantaleo G, Venezia AM (2013) Co3O4 nanocrystals and $\mathrm{Co} 3 \mathrm{O} 4-\mathrm{MOx}$ binary oxides for $\mathrm{CO}, \mathrm{CH} 4$ and VOC oxidation at low temperatures: a review. Catalysis Science \& Technology 3: 3085-3102

Liu H, Fu X, Weng X, Liu Y, Wang H, Wu Z (2014) Catalytic combustion of low concentration methane over catalysts prepared from $\mathrm{Co} /$ Mg-Mn layered double hydroxides. Journal of Chemistry:2014

Liu Y et al (2013) Controlled generation of uniform spherical LaMnO3, $\mathrm{LaCoO} 3, \mathrm{Mn} 2 \mathrm{O} 3$, and $\mathrm{Co} 3 \mathrm{O} 4$ nanoparticles and their high catalytic performance for carbon monoxide and toluene oxidation. Inorganic Chemistry 52:8665-8676. https://doi.org/10.1021/ic400832h

Luo L, Chen S, Xu Q, He Y, Dong Z, Zhang L, Zhu J, Du Y, Yang B, Wang C (2020) Dynamic atom clusters on $\mathrm{AuCu}$ nanoparticle surface during $\mathrm{CO}$ oxidation. Journal of American Chemical Society 142(8):4022-4027

Ly H 2002 Effects of natural gas composition variations on the operation, performance and exhaust emissions of natural gas-powered vehicles. In: NGV 2002 Conference Paper-Effects of Gas Composition-Aug, 2002

Lyubovsky M, Pfefferle L (1998) Methane combustion over the $\alpha$ alumina supported Pd catalyst: activity of the mixed $\mathrm{Pd} / \mathrm{PdO}$ state. Applied Catalysis A: General 173:107-119

Machocki A et al (2004) Manganese-lanthanum oxides modified with silver for the catalytic combustion of methane. Journal of Catalysis 227:282-296. https://doi.org/10.1016/j.jcat.2004.07.022

Mahara Y, Tojo T, Murata K, Ohyama J, Satsuma A (2017) Methane combustion over $\mathrm{Pd} / \mathrm{CoAl} 2 \mathrm{O} 4 / \mathrm{Al} 2 \mathrm{O} 3$ catalysts prepared by galvanic deposition. RSC Advances 7:34530-34537

Mankidy B, Balakrishnan N, Joseph B, Gupta V (2014) CO oxidation by cobalt oxide: an experimental study on the relationship between nanoparticle size and reaction kinetic Austin. Journal of Chemical Engineering 1:1-6

Martínez-Lozano G, Hesiquio-Garduño M, Zeifert B, Salmones J (2007) Structural and microstructural characterization of Co-hydrotalcitelike compounds by X-ray diffraction. Journal of Alloys and Compounds 434:816-819

McCarty J, Chang Y-F, Wong V, Johansson E (1997) Kinetics of high temperature methane combustion by metal oxide catalysts. Preprints-American Chemical Society Division of Petroleum Chemistry 42:158-162

McCarty JG (1995) Kinetics of PdO combustion catalysis. Catal Today 26:283-293

Meng M, Lin P-Y, Y-1 F (1997) The catalytic removal of CO and NO over $\mathrm{Co}-\mathrm{Pt}(\mathrm{Pd}, \mathrm{Rh}) / \gamma-\mathrm{Al} 2 \mathrm{O} 3$ catalysts and their structural characterizations. Catal Lett 48:213-222

Miao S, Deng Y (2001) Au-Pt/Co3O4 catalyst for methane combustion. Applied Catalysis B: Environmental 31:L1-L4. https://doi.org/10. 1016/S0926-3373(01)00122-9

Mishra A, Prasad R (2015) Development of highly efficient doublesubstituted perovskite catalysts for abatement of diesel soot emissions. Clean Technologies and Environmental Policy 17:2337-2347

Mokhtar M, Basahel SN, Al-Angary Y (2010) Nanosized spinel oxide catalysts for $\mathrm{CO}$-oxidation prepared via $\mathrm{CoMnMgAl}$ quaternary hydrotalcite route. Journal of Alloys and Compounds 493:376-384

Najjar H, Lamonier J-F, Mentré O, Giraudon J-M, Batis H (2011) Optimization of the combustion synthesis towards efficient LaMnO3+y catalysts in methane oxidation. Applied Catalysis B: Environmental 106:149-159. https://doi.org/10.1016/j.apcatb. 2011.05.019

Nambi Appadurai A (2020) Covid-19 pandemic: lessons for climate crisis. https://indiaclimatedialogue.net/2020/05/22/lessons-covid-19pandemic-holds-for-climate-crisis/

National Research Council (2010) Global sources of local pollution: an assessment of long-range transport of key air pollutants to and from the United States. National Academies Press

Nwaoha C, Iyoke UJ (2013) A review on natural gas utilization and cutting carbon emissions: how viable is compressed natural gas for road vehicle fuel? J Energy Technol Policy 3:37-46

O'Brien K et al (2004) Mapping vulnerability to multiple stressors: climate change and globalization in India. Glob Environ Chang 14: 303-313

Ogur E, Kariuki S (2014) Effect of car emissions on human health and the environment international. Journal of Applied Engineering Research 9:11121-11128

Oh SH, Mitchell PJ (1994) Effects of rhodium addition on methane oxidation behavior of alumina-supported noble metal catalysts. Applied Catalysis B: Environmental 5:165-179

Omaye ST (2002) Metabolic modulation of carbon monoxide toxicity. Toxicology 180:139-150

Osaki T (2020) Activity-determining factors for catalytic $\mathrm{CO}$ and $\mathrm{CH}_{4}$ oxidation on $\mathrm{Pt} / \mathrm{CeO}_{2}-\mathrm{ZrO}_{2}-\mathrm{Al}_{2} \mathrm{O}_{3}$ cryogels. Res Chem Intermed 46:3125-3143 
Pardiwala JM, Patel F, Patel S (2011) Review paper on catalytic converter for automotive exhaust emission gas. https://pdfs.semanticscholar. org/3956/0f862e7752a6b7d193c935d1414305b3e7c5.pdf

Parida KM (1992) Cleaning car smoke Scientific reporter 29:3

Park M-S, Kim J, Kim KJ, Lee J-W, Kim JH, Yamauchi Y (2015) Porous nanoarchitectures of spinel-type transition metal oxides for electrochemical energy storage systems. Physical Chemistry Chemical Physics 17:30963-30977

Pascoli SD, Femia A, Luzzati T (2001) Natural gas, cars and the environment. A (relatively) 'clean' and cheap fuel looking for users. Ecological Economics 38:179-189. https://doi.org/10.1016/S09218009(01)00174-4

Perry D (2017) Current natural gas vehicle statistics. NGV Global, Auckland, New Zealand

Prasad R, Singh P (2012) A review on CO oxidation over copper chromite catalyst. Catalysis Reviews 54:224-279

Prasad R, Singh P (2013) Low temperature complete combustion of a lean mixture of LPG emissions over cobaltite catalysts. Catalysis Science \& Technology 3:3223-3233

Pundir B (2007) Engine emissions: pollutant formation and advances in control technology. Alpha Science International, Limited

Qureshi ZS, Jaseer EA (2018) Silica-supported gold nanocatalyst for CO oxidation. Gold nano-particles Research Highlights. https://doi.org/ 10.5772/intechopen. 80620

Raj A (2016) A review of mobile and stationary source emissions abatement technologies for natural gas engines. Johnson Matthey Technol Rev 60:228-235

Rattan G, Kumar M (2014) Carbon monoxide oxidation using cobalt catalysts: a short review. Chemistry \& Chemical Technology

Rudolf W (1994) Concentration of air pollutants inside cars driving on highways and in downtown areas. Sci Total Environ 146:433-444

Saber O, Zaki T (2014) Carbon monoxide oxidation using $\mathrm{Zn}-\mathrm{Cu}-\mathrm{Ti}$ hydrotalcite-derived catalysts. Journal of Chemical Sciences 126: 981-988

Seeburg D et al (2018) Structural changes of highly active $\mathrm{Pd} / \mathrm{MeOx}(\mathrm{Me}$ $=\mathrm{Fe}, \mathrm{Co}, \mathrm{Ni}$ ) during catalytic methane combustion. Catalysts 8:42

Seiyama T (1992) Total oxidation of hydrocarbons on perovskite oxides. Catal Rev 34:281-300

Semin RAB (2008) A technical review of compressed natural gas as an alternative fuel for internal combustion engines. Am J Eng Appl Sci $1: 302-311$

Shelef M, Otto K, Gandhi H (1968) The oxidation of $\mathrm{CO}$ by $\mathrm{O}_{2}$ and by $\mathrm{NO}$ on supported chromium oxide and other metal oxide catalysts. Journal of Catalysis 12:361-375

Shinjoh H (2006) Rare earth metals for automotive exhaust catalysts. Journal of Alloys and Compounds 408-412:1061-1064. https:// doi.org/10.1016/j.jallcom.2004.12.151

Sierzchula W, Bakker S, Maat K, van Wee B (2012) Technological diversity of emerging eco-innovations: a case study of the automobile industry. Journal of Cleaner Production 37:211-220. https://doi.org/ 10.1016/j.jclepro.2012.07.011

Solsona BE, Garcia T, Jones C, Taylor SH, Carley AF, Hutchings GJ (2006) Supported gold catalysts for the total oxidation of alkanes and carbon monoxide. Applied Catalysis A: General 312:67-76

Song K-S, Xing Cui H, Kim SD, Kang S-K (1999) Catalytic combustion of $\mathrm{CH} 4$ and $\mathrm{CO}$ on $\mathrm{La} 1-\mathrm{xMxMnO} 3$ perovskites. Catalysis Today 47:155-160. https://doi.org/10.1016/S0920-5861(98)00295-8

Song W, Poyraz AS, Meng Y, Ren Z, Chen S-Y, Suib SL (2014) Mesoporous $\mathrm{Co} 3 \mathrm{O} 4$ with controlled porosity: inverse micelle synthesis and high-performance catalytic $\mathrm{CO}$ oxidation at $-60^{\circ} \mathrm{C}$. Chemistry of Materials 26:4629-4639

Spath PL, Mann MK (2000) Life cycle assessment of a natural gas combined cycle power generation system. National Renewable Energy Lab, Golden, CO (US)

Speight JG (2013) Shale gas production processes. Gulf Professional Publishing
Stasinska B, Machocki A, Antoniak K, Rotko M, Figueiredo JL, Gonçalves F (2008) Importance of palladium dispersion in $\mathrm{Pd} /$ $\mathrm{A} 12 \mathrm{O} 3$ catalysts for complete oxidation of humid low-methane-air mixtures. Catal Today 137:329-334

Stone R (1999) Introduction to internal combustion engines. SAE Intl, Troy, MI

Takehira K, Shishido T, Wang P, Kosaka T, Takaki K (2004) Autothermal reforming of $\mathrm{CH} 4$ over supported Ni catalysts prepared from $\mathrm{Mg}-\mathrm{Al}$ hydrotalcite-like anionic clay. Journal of Catalysis 221: $43-54$

Tang X, Hao J, Li J (2009) Complete oxidation of methane on Co3O4$\mathrm{SnO} 2$ catalysts. Frontiers of Environmental Science \& Engineering in China 3:265-270

Tao FF et al (2015) Understanding complete oxidation of methane on spinel oxides at a molecular level. Nature Communications 6:7798

Task Force on Hemispheric Transport of Air Pollution (2007) Interim report. United Nations Economic Commission for Europe, New York and Geneva

Tatarchuk T, Bououdina M, Vijaya JJ, Kennedy LJ Spinel ferrite nanoparticles: synthesis, crystal structure, properties, and perspective applications. In: International Conference on Nanotechnology and Nanomaterials, 2016. Springer, pp 305-325

Tripati S, Vora K, Bandodkar S (2002) Marine archaeological research in India. In: Settar, S.; Korisettar, R. (eds) Archaeology and historiography: history, theory and method (Indian Archaeol. Retrospect). New Delhi: Manohar and ICHR:353-392

Trivedi S, Prasad R (2016) Reactive calcination route for synthesis of active $\mathrm{Mn}-\mathrm{Co} 3 \mathrm{O} 4$ spinel catalysts for abatement of $\mathrm{CO}-\mathrm{CH} 4$ emissions from $\mathrm{CNG}$ vehicles. Journal of Environmental Chemical Engineering 4:1017-1028. https://doi.org/10.1016/j.jece.2016.01. 002

Trivedi S, Prasad R (2017a) Choice of precipitant and calcination temperature of precursor for synthesis of $\mathrm{NiCo} 2 \mathrm{O} 4$ for control of $\mathrm{CO}$ $\mathrm{CH} 4$ emissions from $\mathrm{CNG}$ vehicles. Journal of Environmental Sciences

Trivedi S, Prasad R (2017b) Selection of cobaltite and effect of preparation method of $\mathrm{NiCo} 2 \mathrm{O} 4$ for catalytic oxidation of $\mathrm{CO}-\mathrm{CH} 4$ mixture Asia-Pacific. Journal of Chemical Engineering

Trivedi S, Prasad R (2018) Synthesis of K-Pd doped NiCo2O4-[small delta] by reactive calcination route for oxidation of $\mathrm{CO}-\mathrm{CH} 4$ emissions from CNG vehicles. New Journal of Chemistry 42:41424154. https://doi.org/10.1039/C7NJ04902A

Vaccari A (1998) Preparation and catalytic properties of cationic and anionic clays. Catal Today 41:53-71

Veldsink J, Versteeg G, Van Swaaij W (1995) Intrinsic kinetics of the oxidation of methane over an industrial copper (II) oxide catalyst on a $\gamma$-alumina support. The Chemical Engineering Journal and the Biochemical Engineering Journal 57:273-283

Wang H, Li J, Liu W, Xu X, Xi W, Chao L, Zhao R, Qia X, Che L (2020) Enhancing catalytic $\mathrm{CH}_{4}$ oxidation over $\mathrm{Co}_{3} \mathrm{O}_{4} / \mathrm{SiO}_{2}$ core-shell catalyst by substituting Co2p with Mn2p. Journal of Dispersion Science and Technology doi. https://doi.org/10.1080/01932691. 2019.1661257

Wang J, Su Y, Wang X, Chen J, Zhao Z, Shen M (2012) The effect of partial substitution of $\mathrm{Co}$ in $\mathrm{LaMnO} 3$ synthesized by sol-gel methods for NO oxidation. Catalysis Communications 25:106109. https://doi.org/10.1016/j.catcom.2012.04.001

Waters R, Weimer J, Smith J (1994) An investigation of the activity of coprecipitated gold catalysts for methane oxidation. Catalysis Letters 30:181-188

Wei X, Hug P, Figi R, Trottmann M, Weidenkaff A, Ferri D (2010) Catalytic combustion of methane on nano-structured perovskitetype oxides fabricated by ultrasonic spray combustion. Applied Catalysis B: Environmental 94:27-37

Worldwide Emissions Standards (2016). Delphi, Innovation for real world 
Wright G (2015) Fundamentals of medium/heavy duty diesel engines. Jones \& Bartlett Publishers

$\mathrm{Wu} \mathrm{H}$ et al (2015) $\mathrm{Co}_{3} \mathrm{O}_{4}$ particles grown over nanocrystalline $\mathrm{CeO}_{2}$ : influence of precipitation agents and calcination temperature on the catalytic activity for methane oxidation. Catalysis Science \& Technology 5:1888-1901

Xiao T-C, Ji S-F, Wang H-T, Coleman KS, Green MLH (2001) Methane combustion over supported cobalt catalysts. Journal of Molecular Catalysis A: Chemical 175:111-123. https://doi.org/10.1016/ S1381-1169(01)00205-9

Xie X, Li Y, Liu Z-Q, Haruta M, Shen W (2009) Low-temperature oxidation of CO catalysed by $\mathrm{Co} 3 \mathrm{O} 4$ nanorods. Nature 458:746

Xu X, Han H, Liu J, Liu W, Li W, Wang X (2014) Promotional effects of samarium on $\mathrm{Co} 3 \mathrm{O} 4$ spinel for $\mathrm{CO}$ and $\mathrm{CH} 4$ oxidation. Journal of Rare Earths 32:159-169. https://doi.org/10.1016/S1002-0721(14) 60046-6

Xuan W, Xu S, Yuan X, Shen W (2008) Carbon monoxide: a novel and pivotal signal molecule in plants? Plant Signal Behav 3:381-382

Yu Yao Y (1974) The oxidation of hydrocarbons and CO over metal oxides: III. Co3O4. J Catal 33:108-122
Zhang L, Zhang L, Xu G, Zhang C, Li X, Sun Z, Jia D (2017) Lowtemperature $\mathrm{CO}$ oxidation over $\mathrm{CeO} 2$ and $\mathrm{CeO} 2 @ \mathrm{Co} 3 \mathrm{O} 4$ core-shell microspheres. New Journal of Chemistry 41:13418-13424. https:// doi.org/10.1039/C7NJ02542D

Zhang Y et al (2014) The effects of the Pd chemical state on the activity of $\mathrm{Pd} / \mathrm{A} 12 \mathrm{O} 3$ catalysts in $\mathrm{CO}$ oxidation. Catalysis Science \& Technology 4:3973-3980

Zhu J, Gao Q (2009a) Mesoporous MCo2O4 (M = Cu, Mn and Ni) spinels: structural replication, characterization and catalytic application in CO oxidation. Microporous and Mesoporous Materials 124: 144-152. https://doi.org/10.1016/j.micromeso.2009.05.003

Zhu J, Gao Q (2009b) Mesoporous MCo2O4 (M = Cu, Mn and Ni) spinels: structural replication, characterization and catalytic application in CO oxidation. Microporous Mesoporous Mater 124:144-152

Zorn K, Giorgio S, Halwax E, Henry CR, Grönbeck H, Gn R (2010) CO oxidation on technological $\mathrm{Pd}-\mathrm{A} 12 \mathrm{O} 3$ catalysts: oxidation state and activity. J Phys Chem C 115:1103-1111

Publisher's note Springer Nature remains neutral with regard to jurisdictional claims in published maps and institutional affiliations. 